Original Research Paper

\title{
The Arid3a Transcription Factor Rescues Natural and RAS- V12-Induced Senescence Via a Rb-Dependent Pathway
}

\author{
${ }^{1,2}$ Christian Schmidt, ${ }^{2}$ Dongkyoon Kim, ${ }^{2}$ Shawn Mathur, ${ }^{2}$ David Covarrubias, ${ }^{2}$ Chhaya Das, \\ ${ }^{3}$ Mark A. Brown, ${ }^{1}$ Joachim Storsberg and ${ }^{2}$ Haley O. Tucker \\ ${ }^{I}$ Department of Biomaterials and Healthcare, Division of Life Science and Bioprocesses, \\ Fraunhofer-Institute for Applied Polymer Research (IAP), 14476 Potsdam-Golm, Germany \\ ${ }^{2}$ Molecular Biosciences, Institute for Cellular and Molecular Biology, \\ University of Texas at Austin, Austin, Texas 78715, USA \\ ${ }^{3}$ Department of Clinical Sciences, Colorado State University, Fort Collins, Colorado, 80523, USA
}

Article history

Received: 24-09-2017

Revised: 28-09-2017

Accepted: 03-11-2017

Corresponding Author: Christian Schmidt

Department of Biomaterials and Healthcare, Division of Life Science and Bioprocesses, Fraunhofer-Institute for Applied Polymer Research (IAP), Potsdam-Golm, Germany

Email: Christian.schmidt@iap.fraunhofer.de

\begin{abstract}
Primary cells are protected against oncogenic events by undergoing premature cellular senescence - an irreversible cell cycle arrest activated by mitogenic signaling as well as by overexpression of tumor suppressors, including p16INK4A, p53 and PML. In the human, downregulation of Dril1/E2F-BP1, a transcriptional regulator of E2F, promotes PML-dependent premature senescence and bypass of antiproliferative signaling by $\mathrm{p} 19 \mathrm{Arf} / \mathrm{p} 53 / \mathrm{p} 21 \mathrm{Cip} 1$ and $\mathrm{p} 16 \mathrm{INK} 4 \mathrm{a}$ to prevent both RasV12-induced and spontaneous senescence. The mouse ortholog, Arid3A/Bright, while highly characterized in B lymphocytes for its function in immunoglobulin transcription and hematopoiesis, had yet to be assessed for a function in growth control. That, along with the considerable sequence/exon structure diversion from its human orthologs, prompted us to evaluate Arid3a in this context. We report that reduction of Arid3a levels in B lymphocytes results in G1/S cell cycle arrest whereas overexpression of Arid3a leads to accumulation of Cyclin E, hyperphosphorylation of $\mathrm{pRb}$, increased transcriptional activity of $\mathrm{E} 2 \mathrm{~F} 1$ and transformation in vivo. Arid3a associates with $\mathrm{pRb}$ in chromatin to release HDAC1 from the E2F1 promoter in proliferating cells. Arid3a mutants that fail to associate with $\mathrm{pRb}$ neither rescue senescence nor induce proliferation. Our results identify a function for Arid3 in cell cycle progression beyond its previously established role in immunoglobulin gene transcription.
\end{abstract}

Keywords: Arid3a, Ras, Senescence, Immortalization

\section{Introduction}

The idea that somatic mutations contribute to the genesis of malignant lesions led to the cloning and characterization of oncogenes and tumor suppressors (Knudson, 2000; 2001). Activation of oncogenes or inactivation of tumor suppressors leads to a form of cellular senescence that can be distinguished from replicative senescence (or crisis) due to telomere loss (Fridman and Tainsky, 2008; Kuilman and Peeper, 2009). Introduction of ras carrying an oncogenic mutation in its GTPase domain (Ha-rasV12 (Serrano et al., 1997a)) into primary fibroblasts results in the induction of various anti-proliferative proteins, including p16INK4a, p21Cip1 and p53 (Kortum et al., 2006). The accompanying cell cycle arrest resembles normal senescence, given its irreversible character and the upregulation of senescence-associated markers such as acidic $\beta$ galactosidase activity (Dimri et al., 1995; Kurz et al., 2000). Loss of the alternative INK4a product p19ARF also collaborates with Ha-rasV12 in oncogenic transformation (Kamijo et al., 1997) and is required for induction of p53 by Ha-rasV12 (Palmero et al., 1998). Members of the retinoblastoma $(\mathrm{Rb})$ tumor suppressor gene family play an important role in protecting cells against the proliferative effects of Ha-rasV12 (Sage et al., 2000; Peeper et al., 2001).

Not only tumor suppressor gene deficiency, but also co-expression of specific oncogenes can bypass HarasV12-induced senescence and facilitate oncogenic 
transformation. For example, c-myc and adenovirus e1a each immortalize primary rodent fibroblasts and collaborate with Ha-rasV12 in oncogenic transformation (Land et al., 1983; Ruley, 1983; Weinberg, 1997; 1989). Together, these observations help explain why immortalizing events can disrupt the normal antioncogenic response to excessive RasV12 signaling and suggest that premature senescence may act as a tumor-suppressing mechanism (Leal et al., 2008; Lleonart et al., 2009).

The DRTF1/E2F1 complex functions as a master regulator of $\mathrm{G} 1$ to $\mathrm{S}$ phase cell-cycle progression (Wong et al., 2011; Docquier et al., 2012). E2F1 binds preferentially to Retinoblastoma protein $(\mathrm{pRb})$ in a cellcycle-dependent manner. E2FBP1/DRIL1, the charter member of the 12 membered A/T-rich Interaction Domain (ARID) family (Wilsker et al., 2005) was initially characterized (Suzuki et al., 1998) as an E2F1 binding factor whose overexpression increases E2F/DP-dependent transcription (Kortschak et al., 1998; 2000). E2FBP1 was also shown to repress simplex virus type 1 infection (Fukuyo et al., 2011) as well as formation of Promyelocytic Leukemia Nuclear Bodies (PML-NBs) (Fukuyo et al., 2004a) which are critical in the control of cellular senescence and stem cell self-renewal (Fukuyo et al., 2004; Ferbeyre et al., 2000; Pearson et al., 2000; Guo et al., 2000).

In a parallel set of experiments, Peeper et al. (2002) fibroblasts harboring the temperature sensitive mutant of the SV40 large T antigen (tsA58), thereby creating the Btr cell line (Peeper et al., 2002; Jat and Sharp, 1989; Tegtmeyer, 1975). Using a retroviral cDNA screen, Peeper et al. (2002) isolated human Drill (Kortschak et al., 1998) as a factor capable of rescuing Btr fibroblasts from RasV12-induced senescence. They further demonstrated that Drill over-expression, although independent or downstream of $\mathrm{pRb}$, was capable of both immortalizing and in combination with rasV12, transforming normal mouse fibroblasts in culture and in vivo.

For instance, growth of human fibroblasts can be prolonged (up to 30 population doublings) by ectopic expression of the simian virus large $\mathrm{T}$ antigen (SV40 large $\mathrm{T}$ ), which is transcribed early during viral infection by SV40 and associates preferentially with the un- or hypo-phosphorylated form of the retinoblastoma $(\mathrm{Rb})$ tumor suppressor family (Knudson, 2001; Fiers et al., 1978; Ludlow et al., 1989; Macera-Bloch et al., 2002).

The promyelocytic protein PML is involved in the regulation of Ha-rasV12-induced senescence, by influencing the acetylation of p53 (Ferbeyre et al., 2000; Pearson et al., 2000).

Arid3a-interacting proteins include ubc9 and PIAS1, leading to its paralog, Bdp. Bdp/Arid3b was cloned as a protein that associates directly via its ARID domain with $\mathrm{Rb}$ (Numata et al., 1999). While E2FBP1/Drill is expressed broadly in human tissues, its mouse (m) ortholog, Arid3a/Bright (for B cell regulator of $\operatorname{IgH}$ transcription) (Herrscher et al., 1995) is expressed exclusively in developing hematopoietic lineages within the embryo and placenta (Rhee et al., 2014; 2017), but restricted to B lymphocytes in the adult (Webb et al., 1998; Nixon et al., 2004). Arid3a, in a complex with Bruton's tyrosine kinase (btk) and TFII-I, binds to specific AT-rich motifs within the nuclear matrixattachment regions (MARs) of the $\mathrm{IgH}$ intronic enhancer $(\mathrm{E} \mu)$ resulting in an activated transcription of heavy chain $\mu$ chains (Herrscher et al., 1995; Kim and Tucker, 2006; Lin et al., 2007; Rajaiya et al., 2005; 2006; Webb et al., 1999; 2000). Arid3a transactivation is dependent on a second, highly conserved, multifunctional domain called REKLES (Kim and Tucker, 2006; Kim et al., 2007; Schmidt et al., 2009). Motifs within REKLES mediate active cytoplasmicnuclear shuttling, homo-tetramerization and heterologous protein-protein interactions. REKLESmediated interactions with Sumo-1 E2 and E3 conjugation enzymes (ubc9 and PIAS-1) led to the finding that a fraction of Arid3a-as with its human homolog (Fukuyo et al., 2004) — was Sumo-I modified and partitioned into PML-nuclear bodies (Schmidt et al., 2009; Zong et al., 2000). Mutation of the single SUMO-I conjugation site in Arid3a had no effect on DNA binding or transcriptional activities, leaving the role of Bright in PML-NB unresolved (Schmidt et al., 2009).

While the ARID DNA-binding domains are 98\% identical among human and mouse orthologs, the orthologs, in total, are less than $80 \%$ conserved (Peeper et al., 2001; Herrscher et al., 1995). They align particularly poorly from residues 26-240 (just N-terminal to their ARIDs) where 15 gaps are required to achieve an identity/similarity of 75/85\% (Wilsker et al., 2005). Conserved within this region for mouse, but not for human, is an acidic stretch, which meets consensus requirements for 3 tandem PEST motifs (Wilsker et al., 2005). PEST domains have been shown in several cases to target ubiquitin-mediated proteasome degradation (Melchior, 2000). Thus, the human and mouse proteins have considerable opportunity for structure-function based differences.

Here we report that, despite these differences, murine Arid3a immortalizes Mouse Embryonic Fibroblasts (MEFs) and protects them both from spontaneous and Ha-rasV12-induced senescence independent (or upstream) of p19ARF or p53 signaling. This activity of Arid3a is dependent upon cytoplasmicnuclear shuttling, DNA binding and association with $\mathrm{pRb}$, but not upon Sumo-I modification. Cell cycle progression results from inactivation of the $\mathrm{Rb}$ tumor suppressor pathway through accumulation of Cyclin E, hyper-phosphorylation of $\mathrm{pRb}$ and activation of E2F1 via loss of promoter-associated HDAC complexes. 


\section{Results}

Comparisons of Human (h) and Mouse (m) Arid3a to Rescue Senescence in vitro and in vivo

Full-length (1-601) HA-tagged $\mathrm{m}$ and hArid3a were engineered, packaged into pBABE-puro retroviruses (Peeper et al., 2002) and infected alone or in combination with Ha-tagged RasV12 MEFs. After 1-2 days, cultures were selected with puromycin $(2 \mathrm{mg} / \mathrm{ml})$ for an additional 4 days and their ability to proliferate was determined (Fig. 1A). As expected, RASV12 expression led to premature senescence and the cells adopted typical morphology (Fig. 1A), as confirmed by acidic B-galactasidase staining (Fig. 1B). Focus forming assays showed that, in 2 weeks, hArid3a + Ha-RasV12 rescued cells were morphologically transformed, had lost their ability to stop proliferating upon contact inhibition (Fig. 1C). Although mArid3a + Ha-RasV12 coexpressing MEFs also underwent transformation, there were consistently fewer transformed colonies which required significantly longer time $(\sim 3$ weeks $)$ to develop. These differences in efficiency were not the result of differences in expression (Fig. 1C), nor in anchorageindependent growth characteristics (data not shown). Both, murine and human Arid3a + RASV12 infected cultures continued to proliferate and bypassed senescence as early as 7 days (passages) post selection. Control cells were senescent whereas mBRIGHT + RASV12 cells were proliferating rapidly (data not shown).
A hallmark of transformed cultured cells is their ability to form tumors in nude mice. Peeper et al. (2002) observed tumor formation for DRIL1/hArid3a $+\mathrm{Ha}-$ RasV12 transformed MEFs but not for hArid3a alone immortalized MEFs. We employed the identical experiments with mArid3a+Ha-RasV12 transduced lines. Six days after retroviral infection, $\sim 10^{6} \mathrm{MEFs}$ were injected subcutaneously into each flank of 12 nude mice. $\mathrm{hArid} 3 \mathrm{a}+\mathrm{Ha}-\mathrm{Ras} \mathrm{V} 12 \mathrm{MEFs}$ produced tumors in $10 / 12$ nudes within 10 days (Table 1) hArid3a+Ha-RasV12 MEFs expressing equivalent levels of mArid3a (not shown) formed tumors in nude mice but at a lower frequency (4/13 nudes) and slower rate (12-30 days) than hArid3a+Ha-RasV12 cells.

Therefore, Arid3a from either species can collaborate with Ha-RasV12 to drive cells to transformation in culture and are capable of eliciting tumors in mice, albeit at significantly different penetrance.

\section{Arid3a alone is Sufficient to Immortalize Fibroblasts}

As with hArid3a (Peeper et al., 2002), mArid3a alone is sufficient to immortalize normal primary MEFs. Upon retroviral transduction with mArid3a, MEFs escaped from natural senescence and these cells could be cultured for at least $\sim 3$ months, without loss of proliferation (data not shown). A similar result, also in agreement with (Peeper et al., 2002), was observed when mArid3a was ectopically expressed in NIH/3T3 fibroblasts.

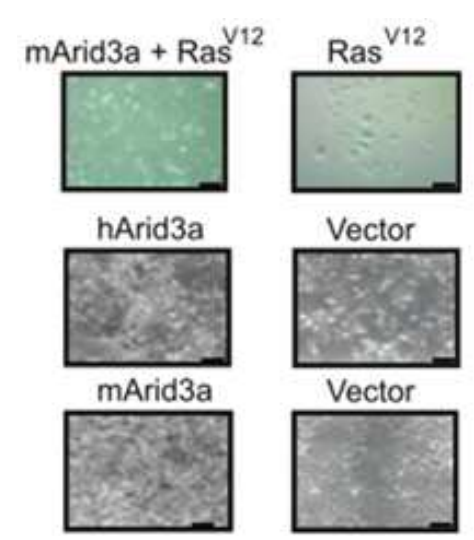

(A)

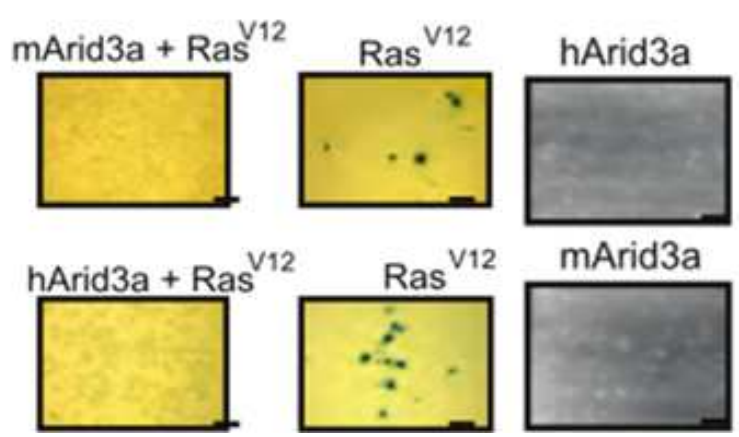

(B)

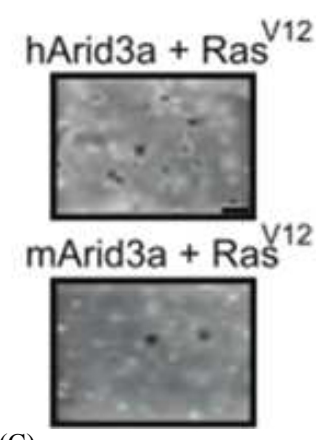

(C)

Fig. 1: Mouse (m) and human (h) Arid3a share some but not all features of immortalization and transformation. (A) Expression of either $\mathrm{h}$ or mArid3a rescues mouse embryonic fibroblasts (MEF; E15) from Ha-ras ${ }^{\mathrm{V} 12}$-dependent morphological senescence. MEFs were infected with retroviruses expressing Ha-Ras ${ }^{\mathrm{V} 12}$ either with a vector containing no insert (control) or with $\mathrm{h}$ or mArid3a. Approximately 2 weeks later, the MEFs were photographed at 40x magnification. (B) Mouse embryonic fibroblasts co-expressing Arid3a and Ha-Ras ${ }^{\mathrm{V} 12}$ do not stain for senescence-associated b-galactosidase activity. MEFs were infected with retroviruses encoding Ha-ras ${ }^{\mathrm{V} 12}$ and either murine or human Arid3a (as indicated) and incubated for two weeks in a humidified atmosphere, followed by fixation and overnight staining using a buffer consisting of $1 \mathrm{mg} / \mathrm{ml} \mathrm{X}$-gal, $120 \mu \mathrm{M}$ $\mathrm{K}_{3} \mathrm{Fe}[\mathrm{CN}]_{6}, 120 \mu \mathrm{M} \mathrm{K}_{4} \mathrm{Fe}[\mathrm{CN}]_{6}, 1 \mathrm{mM} \mathrm{MgCl}{ }_{2}$ in $\mathrm{PBS}$ at $\mathrm{pH} 6.0$ ) at $37^{\circ} \mathrm{C}$ without $\mathrm{CO}_{2}$. Senescence-associated $\beta$-galactosidase activity is visualized by a blue reaction product. (C) Both $\mathrm{m}$ and hArid3a/Ha-Ras ${ }^{\mathrm{V} 12}$-expressing mouse embryonic fibroblasts proliferate anchorage-independently but with different efficiencies. MEFs infected and selected as in (a) were analyzed in a focus formation assay. Cells were seeded in duplicate into 6 -well plates containing solidified $1 \%$ agar and two weeks later, foci were photographed at 40x magnification 


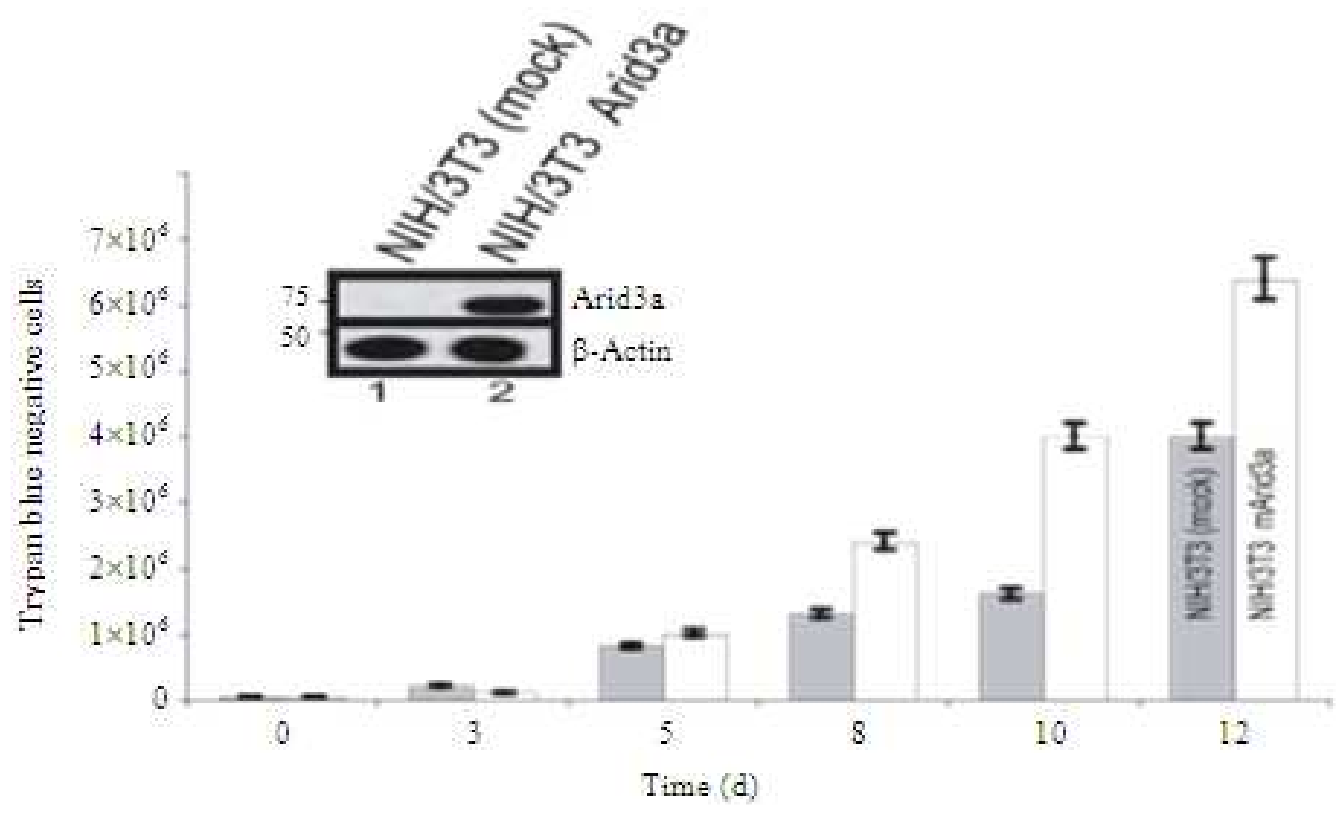

Fig. 2: NIH3T3 fibroblasts stably expressing mArid3a display a growth advantage. NIH/3T3 fibroblasts were infected with a vector containing no insert (control) or with $m A$ rid $3 a$ and subjected to puromycine selection for 5 days. Trypan blue negative cells were counted over the indicated time and Western blotting confirmed presence of mArid3a in infected cells at the end of this experiment. Actin served as loading control

Table 1: Murine and human BRIGHT/RASV12 cells are oncogenic in athymic mice. Nude, athymic mice were injected subcutaneously in both flanks with one million MEFs, expressing cDNAs as indicated. Represented are numbers of tumors per injection, 2 weeks after injection. $\mathrm{M}$ or hBRIGHT-only-expressing cells did not form tumors after 5 weeks

\begin{tabular}{lll}
\hline Cells & Tumor induction & Latency period \\
\hline HA-hBRIGHT & $0 / 4$ & - \\
HA-hBRIGHT/RASV12 & $10 / 10$ & 8 days \\
HA-mBRIGHT & $0 / 6$ & - \\
HA-BRIGHT/RASV12 & $4 / 4$ & $12-30$ days \\
\hline
\end{tabular}

Arid3a expression provided a growth advantage (Fig. 2) without altering the cell cycle profile, as assessed by propidium iodide staining (data not shown). It is concluded that Arid3a increases the proliferative rate of cells.

mArid3a Bypasses Ha-RasV12-Induced Senescence Downstream (or Independent) of Traditional Senescence Regulators

Ha-RasV12-induced senescence requires intact p19Arf and the other INK4a locus-encoded regulator, p16INK4a, which accumulate for more than 2 weeks (Palmero et al., 1998). We monitored the p19Arf response to RASV12 in the absence or presence of $\mathrm{mArid} 3 \mathrm{a}$ retroviruses in whole cell extracts prepared 2 weeks after retroviral transduction (Fig. 3A). No changes were observed, indicating that the cells have become insensitive to elevated levels of both. Because p53 is required for Ha-RasV12-induced senescence (Serrano et al., 1997a), we examined whether mArid3a, either in the presence or absence of HaRasV12, interfered with basal levels of p53 or one of its transcriptional targets, p21Cip1. Westerns of whole cell lysates showed changes in their accumulation (Fig. 3A) even though mArid3a/Ha-RasV12 cells were rapidly proliferating (Fig. 2A).

Telomere shortening is another factor that contributes to onset of replicative senescence, particularly in human cells (Yang, 2008; Zou et al., 2009). Although this effect has not been implicated in oncogenic Ha-RasV12mediated senescence in human cells (Seger et al., 2002), we assayed for its potential contribution to mArid3a rescue in MEFs. Using a TRAP assay, the senescent HaRasV12 transduced cells had the same levels of telomerase activity as mArid3a+Ha-RasV12 coexpressing cells (data not shown).

\section{Bypass of RasV12-Induced Senescence by Arid3a Correlates with Induction of Cyclin E1}

To identify hArid3a targets, other than the candidates above, we measured expression of cell cycle regulators. Both Cyclins D1 and E were previously shown to cooperate with RasV12 in oncogenic 
transformation in vitro and in vivo (Haas et al., 1997; Karsunky et al., 1999). As shown in Fig. 3B, mArid3a-mediated immortalization of MEFs is accompanied by a gradual upregulation of Cyclin E with no significant effects on Cyclin D1 abundance. The kinetics of Cyclin E induction correlated with the passage, abbreviated post induction (pi) in which mock infected MEFs underwent senescence (Fig. 3B). Both $\mathrm{m}$ and hArid3a-expressing fibroblasts continued to proliferate with no apparent lag time (data not shown). Together with (Peeper et al., 2002), the results strongly argue that Cyclin $\mathrm{E}$ is an essential Arid3a target, which contributes to the immortalizing activity of Arid3a.

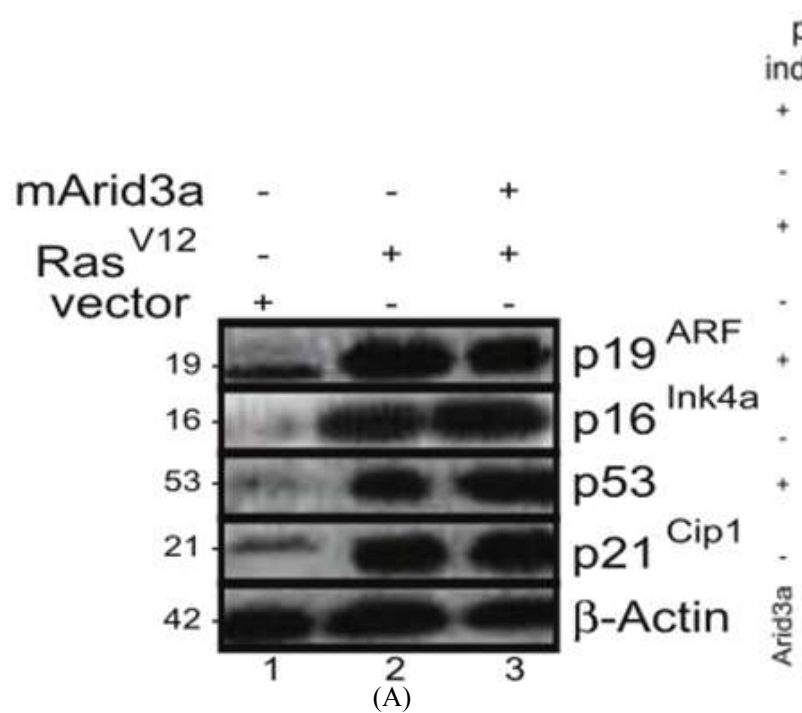

post

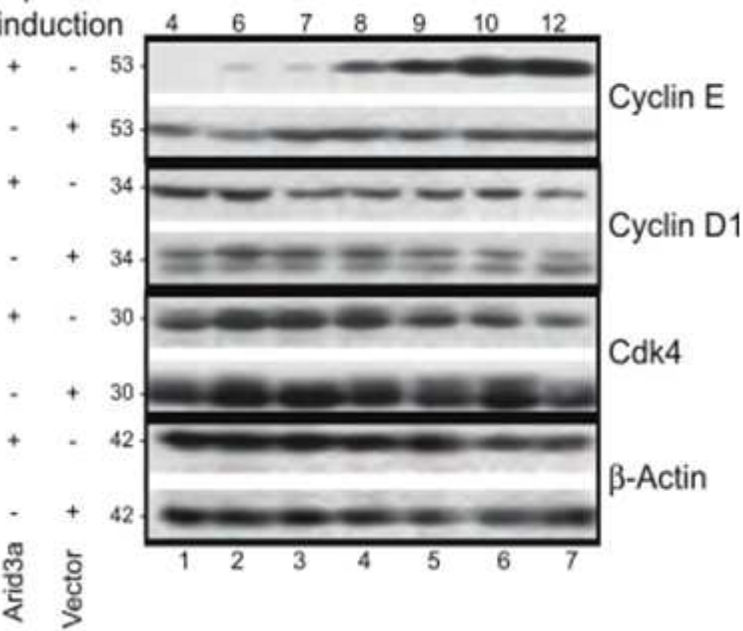

(B)
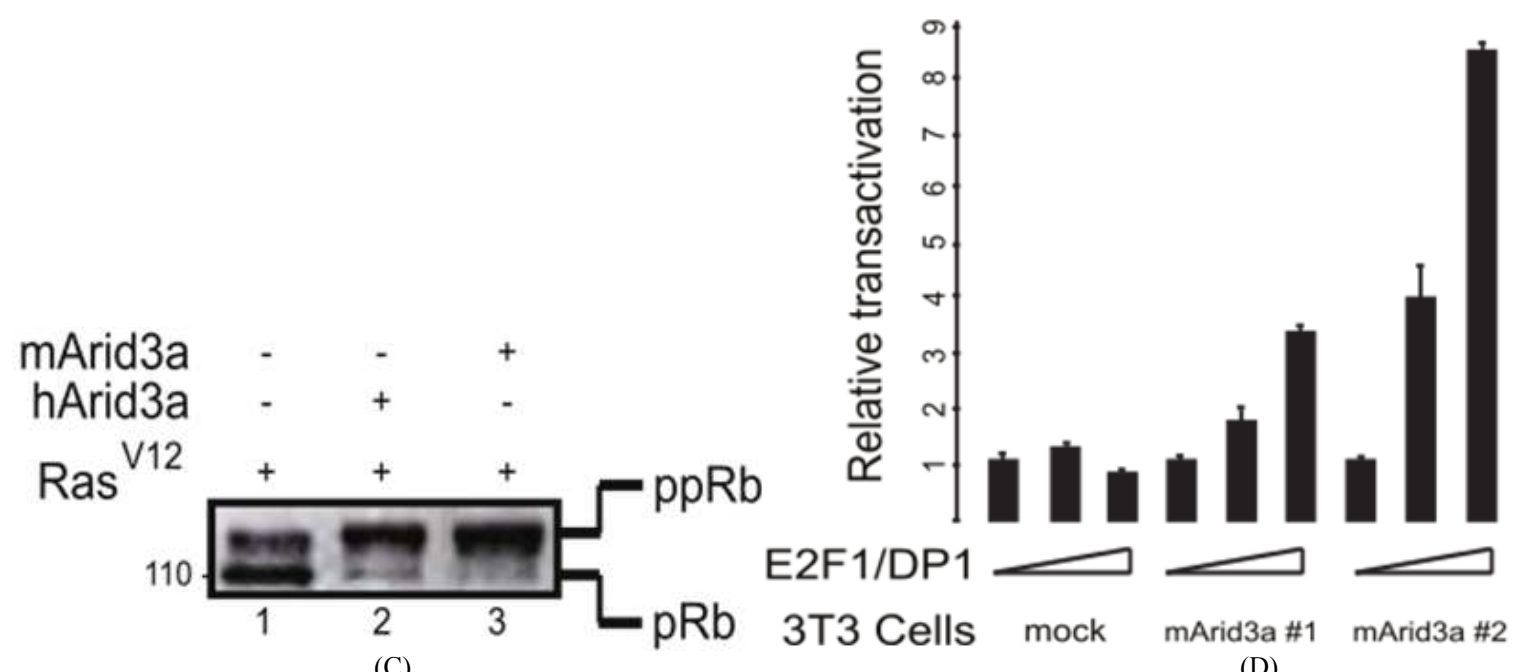

(C)

(D)

Fig. 3: Ectopic expression of mArid3a correlates with induction of Cyclin E, hyper-phosphorylation of p110Rb and increased activity of the E2F1 transcription factor. (A-C) Ectopic expression of mArid3a correlates with induction of Cyclin E, hyperphosphorylation of $\mathrm{p} 110 \mathrm{Rb}$ and does not prevent $\mathrm{Ha}$-ras ${ }^{V 12}$-mediated induction of p19 ${ }^{\mathrm{Arf}}$, p16 ${ }^{\mathrm{INK} 4 \mathrm{a}}$, p53, or p21 ${ }^{\mathrm{Cip} 1}$ but correlates with induction of Cyclin E and hyper-phosphorylation of p110Rb. Primary MEFs were infected with, and selected for, expression of retroviruses expressing either no insert (vector) or HA-tagged mArid3a. MEFs cultures were split twice a week with passages counted post induction, beginning with the first passage after induction. Cell extracts were assayed for protein concentration and 50-80 $\mu \mathrm{g}$ of each were resolved by SDS-PAGE. Western blotting was performed with the indicated antibodies and enhanced chemo-luminescence was used for detection of proteins. (D) mArid3a induces the activity of the E2F1 transcription factor. The independent 3T3 cell pools (established in A-C) were transfected with an E2F-responsive luciferase reporter plasmid, carrying six synthetic E2F1 consensus sites, as well as increasing amounts (indicated by triangles) of expression plasmids encoding E2F1 and its heterodimeric partner DP1. Relative transactivation of the reporter was determined by normalization to a co-transfected Renilla-luciferase internal control and to the reporter activity in the absence of E2F1/DP1. Shown is the mean average of independent triplicates per data point along with standard deviation 


Arid3a Induces the Activity of the E2F1
Transcription Factor via $\quad$ pRb
Hyperphosphorylation

Cell cycle progression from $\mathrm{G} 1$ to $\mathrm{S}$ requires sequential hyperphosphorylation of $\mathrm{pRb}$ to release its repression of E2F (Harbour et al., 1999; Zhang et al., 2000; DeCaprio, 2009). As shown in Fig. 3C, the majority of Ha-RasV12 transduced senescent cells contain pRbp mostly in its hypophosphorylated form. Upon co-infection with either $h$ or mArid3a viruses, most of $\mathrm{pRb}$ was hyperphosphorylated $(\mathrm{ppRb})$ in agreement with the previous data implying that cells released from senescence had entered $S$ phase.

In addition to loss of p19ARF or p53, Rb-family member deficiency bypasses both normal and Ha-RasV12induced senescence (Kortum et al., 2006; Sage et al., 2000; Peeper et al., 2002; Dannenberg et al., 2000). Several critical G1/S Cyclin promoters, including Cyclin E, are regulated by $\mathrm{pRb} / \mathrm{E} 2 \mathrm{~F} 1$ signaling through hyperphosphorylation of $\mathrm{pRb}$ (Ohtani et al., 1995; Komori et al., 2005; Sebastian et al., 2005).

We utilized NIH $3 \mathrm{~T} 3$ cells to measure the effects of mArid3a on E2F activity to avoid the problem of different rates of cell proliferation seen in senescent vs proliferating MEFs. 3T3 cells are immortal and did not alter their cell cycle kinetics upon mArid3a expression (Fig. 2B). Control or mArid3a transduced 3T3 cells were transiently co-transfected with E2F1 and with an E2F-dependent reporter (Suzuki et al., 1998; Ohtani et al., 1995). Levels of E2F1, minimally sufficient to stimulate control luciferase activity, produced significant transactivation of the reporter in the two mArid3a-expressing populations (Fig. 3D). These results show that in the presence of mArid3a expression, E2F1 transcriptional activity is enhanced.

Active Nucleo-Cytoplasmic Shuttling, DNA Binding and Lipid Raft Occupancy Positively Correlate with mArid3a's Ability to Rescue Btr Cells from $\mathrm{Ha}$ RasV12-Induced Premature Senescence

To determine the requirements for Arid3a to rescue from natural senescence, we infected Mouse embryonic fibroblasts at passage 3 with wild type and mutant forms of Arid3a (Fig. 4A; see (Kim and Tucker, 2006; Kim et al., 2007; Schmidt et al., 2009) for details). Two days post-infection, cells were grown under puromycine resistance and Trypan blue negative cells were counted at the time points indicated in Fig. 4B. Whereas wild type Arid3a rescued these cells from natural senescence, the mutant form 401KIKK/AIAA showed similar properties (Fig. 4B and 4C).

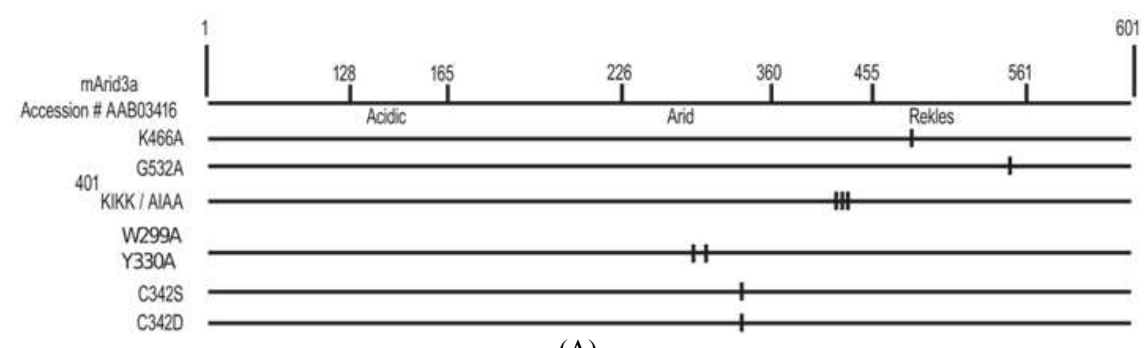

(A)

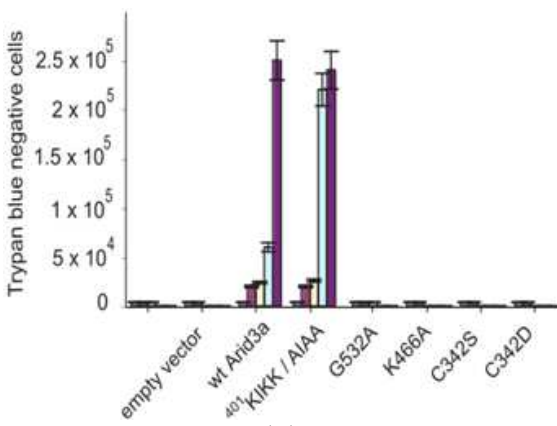

(B)

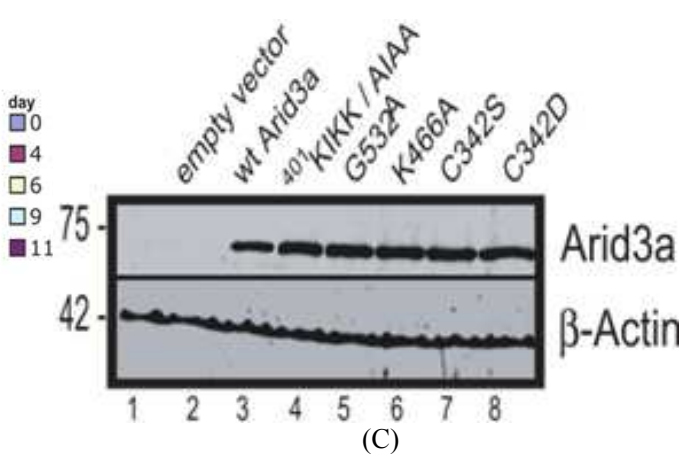

Fig. 4: Cytoplasmic-nuclear shuttling, DNA binding and an intact Arid domain are required for mArid3a to complex with Rb and rescue Btr cells from Ha-ras ${ }^{\mathrm{V} 12}$-induced senescence. (A) Schematic of Bright indicating domains and positions of substitution mutations. (B) Mouse embryonic fibroblasts are rescued from senescence by mArid3a. Primary MEF cells were grown near to the end of their natural life span (passage 3), infected with the indicated forms of mArid3a and selected for puromycine resistance for one passage. Trypan blue negative cells were counted. (C) Confirmation of ectopic expression of mArid3a in the transduced MEF cells. Western analysis of whole cell extract at the end of the experiment described in (B) was to confirm expression of Arid3a using Actin as a loading control 
To confirm this observation, we employed Btr cells (Peeper et al., 2002). Btr cells were grown at the permissive temperature $\left(32^{\circ} \mathrm{C}\right)$ and infected with the indicated forms of Arid3a. After two days, the cells were shifted to the non-permissve temperature $\left(39.5^{\circ} \mathrm{C}\right)$ and incubated for ten days in a humidified atmosphere. Staining for senescence-associated b-galactosidase activity was performed as described by (Dimri et al., 1995), followed by subsequent Eosin counterstaining.

As shown in Fig. 5, all cells are negative for senescence-associated $\beta$-galactosidase activity at the permissive temperature (red color). Only wild type Arid3a and the mutant 401KIKK/AIAA allowed transfectants to grow at the non-permissive temperature; neither the lipid raft localization defective mutant C342S/D (Wilsker et al., 2005; Schmidt et al., 2009), nor the DNA binding inactive form W299A/Y330A (Nixon et al., 2004) allowed transfectants to grow at the non-permissive temperature.

Our co-immunoprecipitation results show that only wild type Arid3a and the mutant 401KIKK/AIAA complex with $\mathrm{Rb}$ at $39.5^{\circ} \mathrm{C}$ (Fig. 6). We conclude that lipid raft occupancy, DNA binding activity and active cytoplasmic-nuclear shuttling are requisite for Arid3a to function as oncogene.

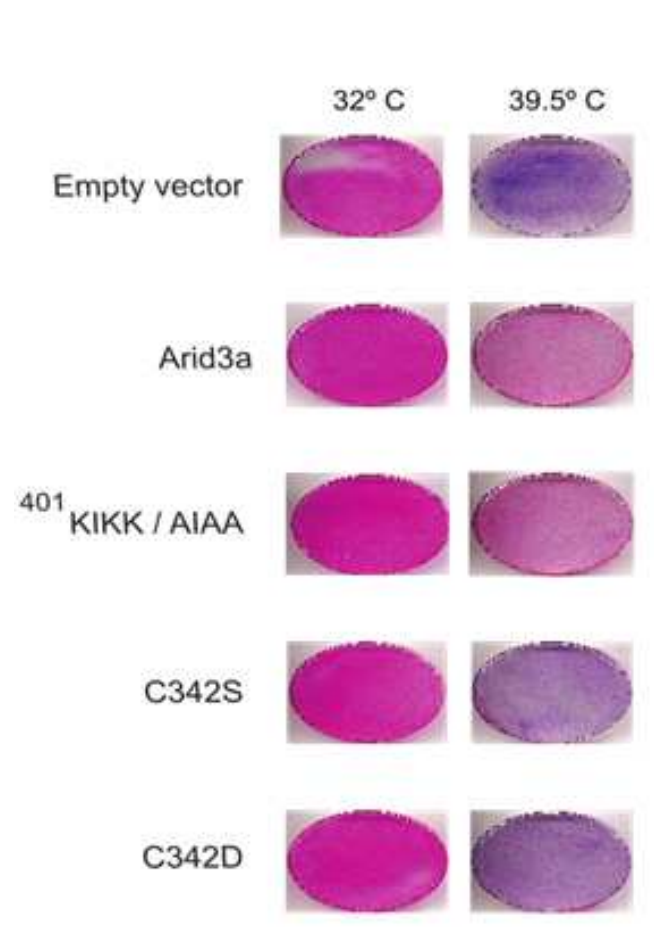

Cytoplasm-Nuclear Shuttling, DNA Binding and Complex Formation with $\mathrm{Rb}$ are Features of Oncogenic Arid3a

Full length Arid3a, its characteristic domains (acidic, ARID and REKLES) and the position of substitution point mutations, sumoylation-consensus motif 401KIKK/AIAA, nuclear export deficient G532A, nuclear import deficient K466A, a conservative and conconservative substitution mutation of the single and conserved cysteine $\mathrm{C} 342 \mathrm{~S} / \mathrm{D}$ along with the dominant negative form W299A/Y330A are summarized in Fig. 4A (Nixon et al., 2004; Kim and Tucker, 2006; Kim et al., 2007; Schmidt et al., 2009).

To determine the requirements for Arid3a to rescue from natural senescence, we used Mouse Embryonic Fibroblast (MEF) cells at the onset of replicative crisis (Kamijo et al., 1997) and assaysed for the ability of Arid3a and its substitution point mutant forms to rescue from naturally occuring senescence. Two days postinfection, MEF cells were grown under puromycine resistance and Trypan blue negative cells were counted at the time points indicated in Fig. 2B. While wild type Arid3a rescued these cells from natural senescence, only the mutant form 401KIKK/AIAA showed similar effects.
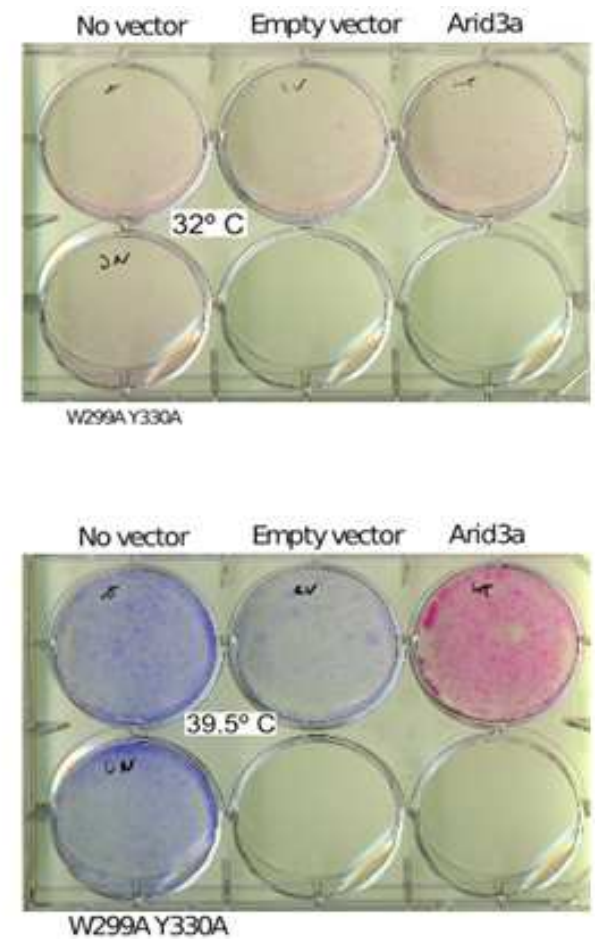

Fig. 5: Requirements of mArid3a to rescue Btr cells from Ha-ras ${ }^{\mathrm{V} 12}$-induced senescence. Btr cells were infected with retroviruses encoding the indicated forms of mArid $3 \mathrm{a}$ and grown at the permissive temperature $\left(32^{\circ} \mathrm{C}\right)$ for three days following shift to the non-permissive temperature $\left(39.5^{\circ} \mathrm{C}\right)$ for ten days. Cells were fixed and stained for senescence-associated $\beta$ galactosidase activity using a buffer consisting of $1 \mathrm{mg} / \mathrm{ml} \mathrm{X}$-gal, $120 \mu \mathrm{M} \mathrm{K}{ }_{3} \mathrm{Fe}[\mathrm{CN}]_{6}, 120 \mu \mathrm{M} \mathrm{K} \mathrm{Fe}[\mathrm{CN}]_{6}, 1 \mathrm{mM} \mathrm{MgCl}_{2}$ in PBS at $\mathrm{pH} 6.0$ ) at $37^{\circ} \mathrm{C}$ without $\mathrm{CO}_{2}$, as described in Fig. 1, followed by counterstaining with Eosin. Photographs of the individual plates are shown 


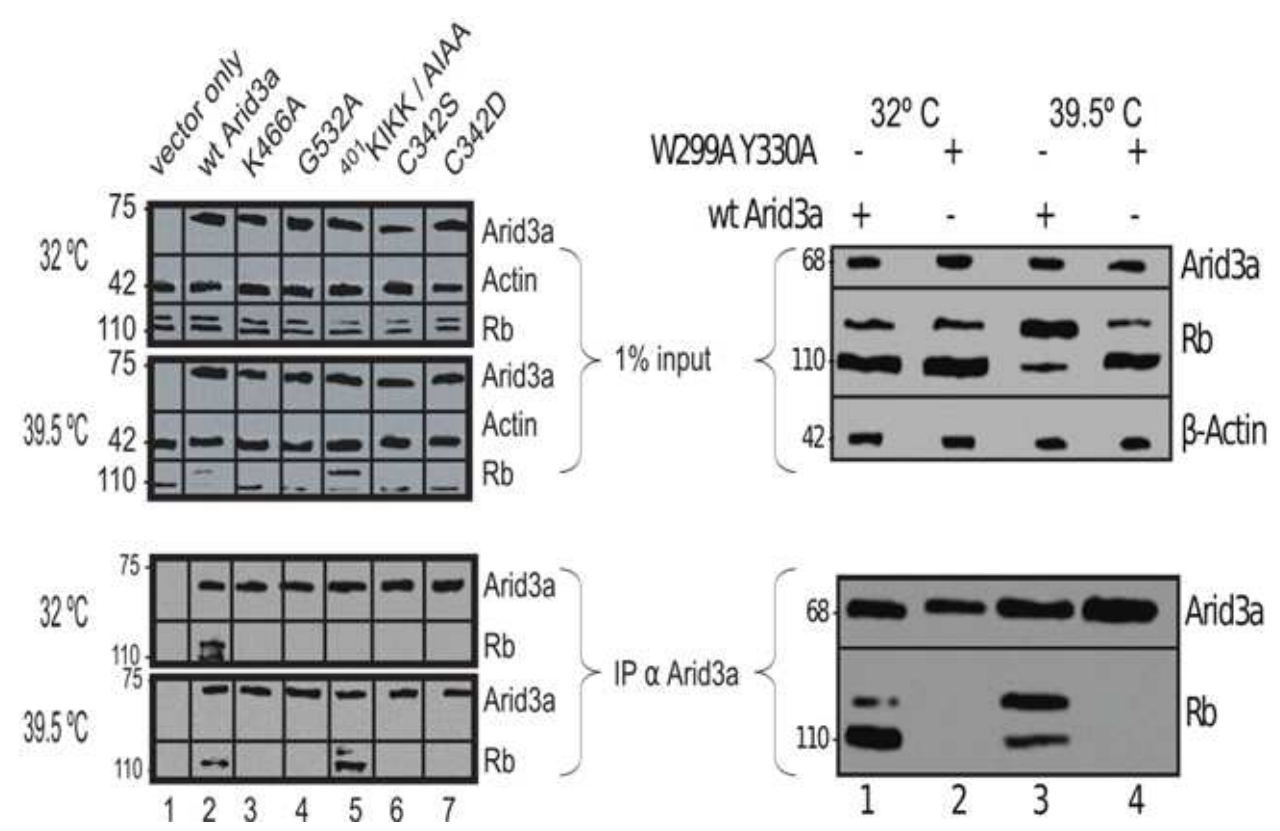

Fig. 6: Cytoplasmic-nuclear shuttling and an intact Arid domain are required for mArid3a to complex with Rb. Btr cells were infected with the indicated retroviruses and treated as described in Fig. 2C. Whole cell lysates were prepared using RIPA buffer $(500 \mathrm{mM} \mathrm{NaCl} ; 10 \mathrm{mM}$ Tris/Cl pH 8; 0.1\% SDS; 5mM EDTA, $\mathrm{pH} 8 ; 10 x$ protease inhibitor [Complete tablet, Roche]; $15 \mathrm{~min}$ on ice) and $0.1 \%$ of the input was probed with antibodies against Arid3a, Actin and Rb. Immunoprecipitation of Arid3a was performed using $200 \mu \mathrm{g}$ of pre-cleared extract and $1 \mu \mathrm{g}$ of anti-Arid3a antiserum, followed by precipitation of the complexes with Protein A sepharose and subsequent Western analysis using anti-Arid $3 \mathrm{a}$ and $\mathrm{Rb}$ antisera, respectively

To verify this observation, we utilized Btr cells (Peeper et al., 2002) to assay for rescue from HaRasV12-induced senescence. Briefly, Btr cells were grown at the permissive temperature $\left(32^{\circ} \mathrm{C}\right)$ and infected with the indicated forms of Arid3a. After two days, the cells were shifted to the non-permissve temperature $\left(39.5^{\circ} \mathrm{C}\right)$ and incubated for ten days in a humidified atmosphere. Staining for senescence-associated bgalactosidase activity was performed as described by (Dimri et al., 1995), followed by subsequent Eosin counterstaining. As shown in Fig. 2C, all cells are negative for senescence-associated b-galactosidase activity at the permissive temperature (red color). Only wild type Arid3a and the mutant 401KIKK/AIAA allowed transfectants to grow at the non-permissive temperature.

Because sequential hyper-phosphoryation of $\mathrm{Rb}$ is one hallmark of cell cycle progression, we determined whether hyper-phosphorylation of $\mathrm{Rb}$ correlated with Arid3a's ability to bypass Ha-RasV12-induced senescence. In Fig. 2D, we show that only wild type Arid3a and the mutant form 401KIKK/AIAA complex with $\mathrm{Rb}$ at $39.5^{\circ} \mathrm{C}$ and this correlated with presence of $\mathrm{Rb}$ species with lower mobility in SDS-PAGE gels, indicative of hyper-phosphorylated $\mathrm{Rb}$ forms. We conclude that fully active Arid3a functions as oncogene, e.g., DNA binding activity and cytoplasmic-nuclear shuttling are required for rescue from natural and HaRasV12-induced senescence.

\section{Arid3a Rescues from Senescence via Interaction and Sequestering of Rb-HDACl Complexes from the E2F1 Promoter}

We found that the transcriptional activity of E2F1 is enhanced in the presence of mArid3a (Fig. 3D). A potential mechanism for this might be $\mathrm{pRb}$ sequestration. However, Arid3a does not contain the typical $\mathrm{Rb}$ binding pocket. However, its highly similar ARID3A paralogue, $\mathrm{BDP}$, has been shown to interact with $\mathrm{pRb}$ through its ARID DNA binding domain, which is $96 \%$ identical with that of Arid3a (Wilsker et al., 2005; Kortschak et al., 1998; 2000; Numata, 1999). Rb binding proteins, Rbp1 and 2, belong to the ARID family, but appear to bind Rb through their LXCXE motifs (Fattaey et al., 1993; Binda et al., 2006). However, this interpretation was challenged by the fact that $100 \mathrm{mM}$ concentration of Rbp1 peptide containing that motif could not inhibit the Rb-Rbbp1 interaction completely (Numata et al., 1999). Based on the Arid3a-BDP sequence identity (Wilsker et $a l ., 2005)$ and our preliminary immunoprecipitation data (Fig. 6), a physical interaction of mArid3a with $\mathrm{pRb}$ is probable. Using Chip assays (see Fig. 7A for the landing regions of the primers used and the predicted amplificon size), we found that, in Btr cells at the permissive temperature, Arid3a is found in precipitable complexes on chromatin that contain $\mathrm{Rb}$ and Hdac1 (Fig. 7B, arrow pointing to the band in lane 4). Chip PCR 
revealed that at Arid3a is detectable at the E2F1 promoter region at the permissive and non-permissive temperature (Fig. 3C, lanes 4 and 6). The inverse experimental approach revealed that HDAC1 is detected in complexes with Arid3a on chromatin only at the permissive temperature (Fig. 7D, lane 4). The corresponding PCR confirmed this finding (Fig. 3E, arrow pointing to the band in lane 4 ). We conclude that Arid3a can rescue senescence via interaction and sequestering of Rb-HDAC1 from E2F1 promoter.

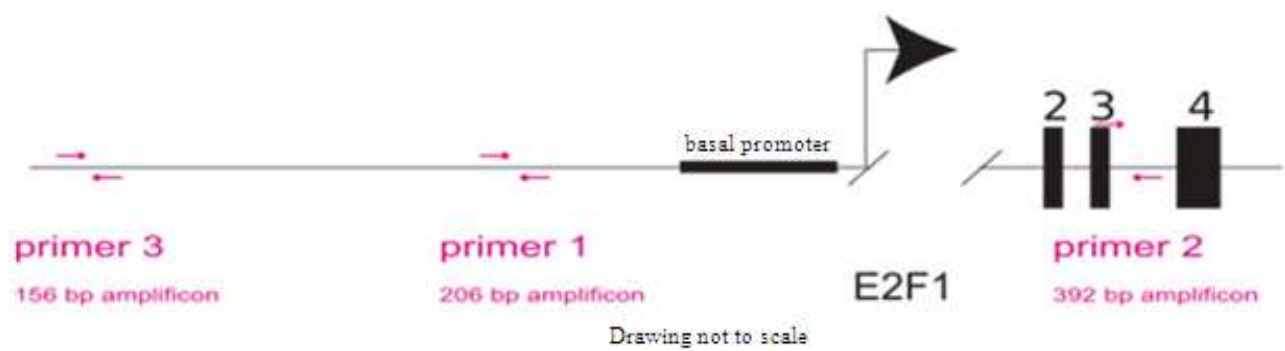

(A)

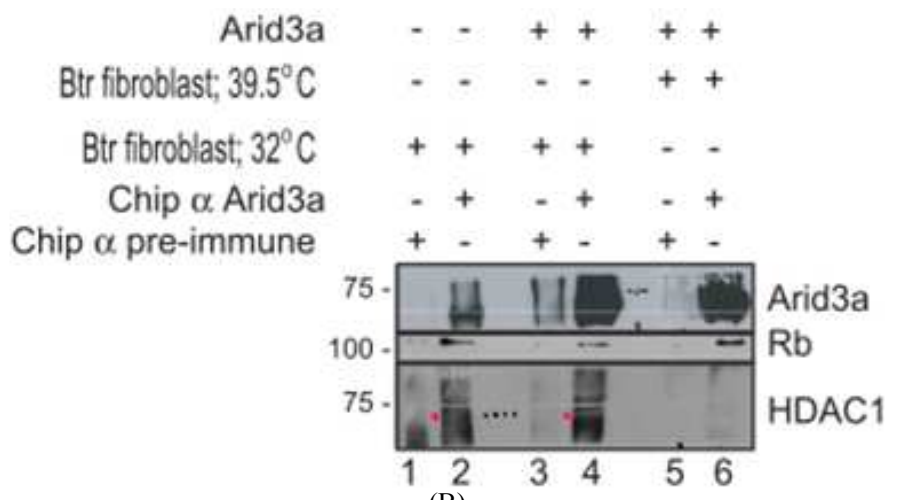

(B)

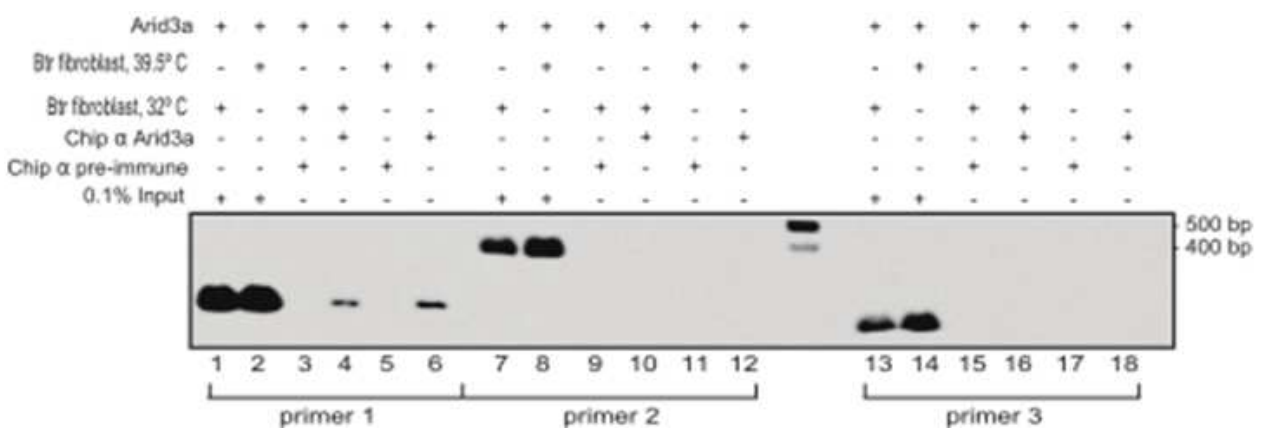

(C)

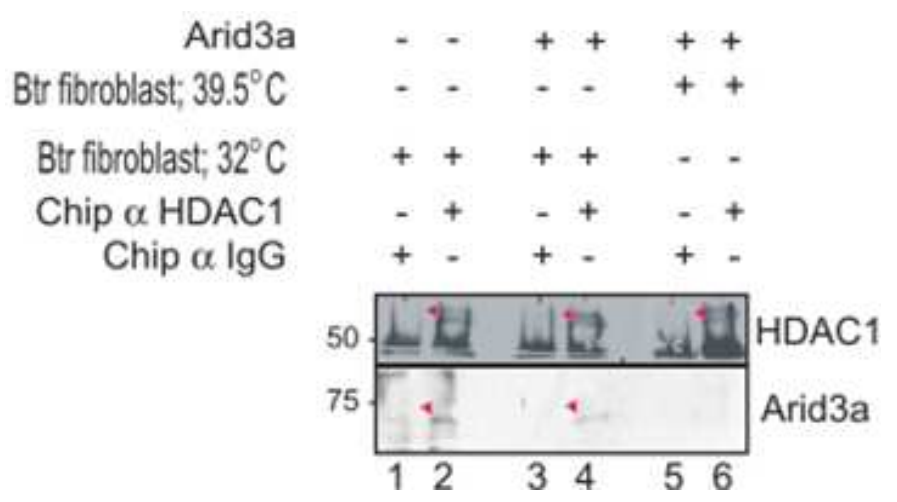

(D) 


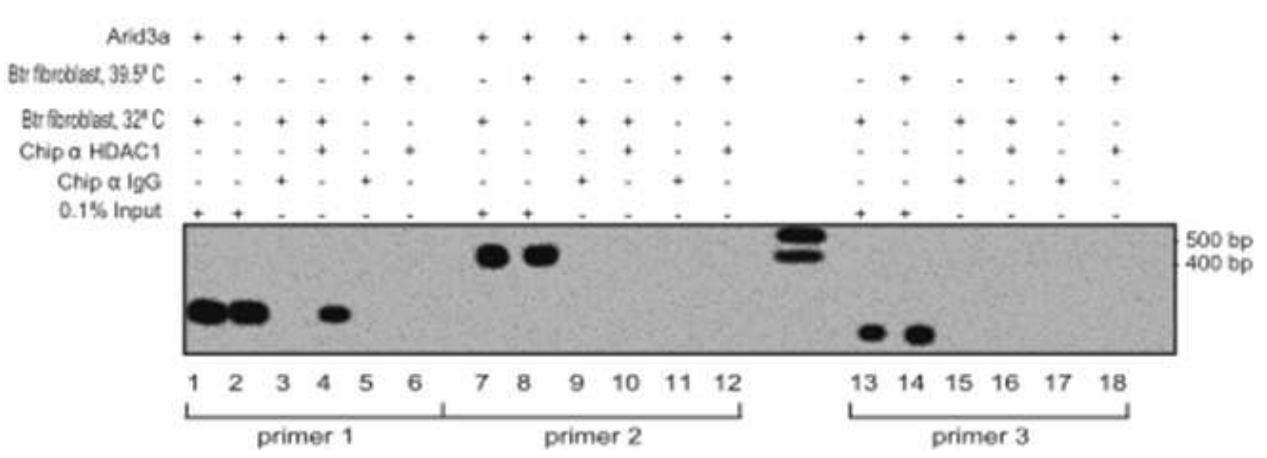

(E)

Fig. 7: Hdac1-associated $\mathrm{mArid} 3 \mathrm{a}$ is stripped of the $\mathrm{Rb}$ binding region of the $\mathrm{E} 2 \mathrm{~F} 1$ promoter at the non-permissive temperature in Btr cells. (A) Schematic and not to scale illustration of primer locations and amplificon sizes. (B-D) Hdac1-associated mArid3a is stripped of the Rb binding region of the E2F1 promoter at the non-permissive temperature in Btr cells. Btr cells were infected with empty retroviruses and mArid3a encoding viruses as indicated and grown at the permissive temperature for two days, followed by shift to the non-permissive temperature for ten days. Cells were fixed to cross-link DNA-protein complexes and subjected to DNA shearing, preparation of cross-linked DNA-protein complexes by IP using the antisera indicated. The DNA-protein complexes were then analyzed by Western (B and D) and disrupted by reversion of the cross link and DNA was extracted, followed by PCR and Southern hybridization using radiolabeled primers (C and E)

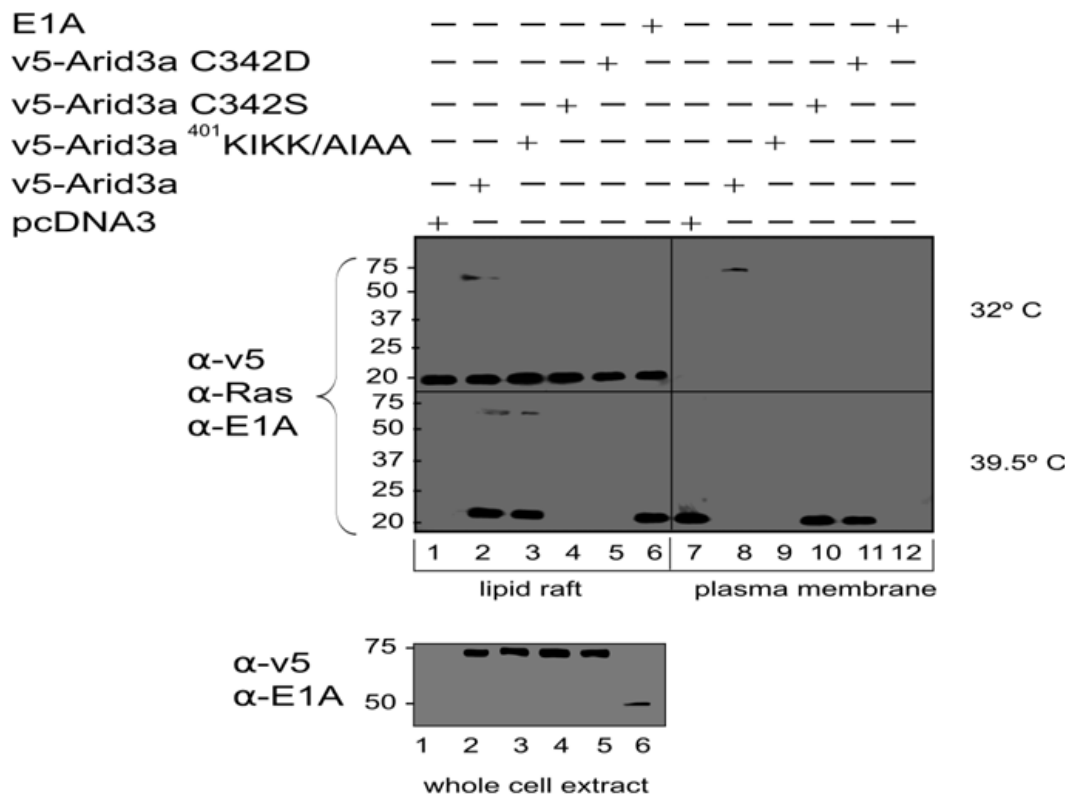

Fig. 8: E1A, Arid3a and the ${ }^{401}$ KIKK/AIAA substitution mutant retain Ha-ras ${ }^{\mathrm{V} 12}$ in lipid rafts at the non-permissive temperature $39.5^{\circ} \mathrm{C}$ in Btr cells. Btr cells were infected with retroviruses encoding the indicated products and grown at the permissive temperature for two days following shift to the non-permissive temperature for ten days. Lipid rafts were prepared by separating crude plasma membrane from lipid rafts using a discontinous gradient centrifugation in ice-cold TNE buffer exactly as described in an earlier publication (Schmidt et al., 2009). Lipid rafts (buyoant fraction) and plasma membranes (sedimenting fraction) were collected and analyzed by Western blotting using the antibodies indicated. Expression of the targets was confirmed by probing RIPA whole cell extracts with the antibodies indicated

E1A, Arid3a and the Arid3a 401KIKK/AIAA Substitution Mutant Retain Ha-rasV12 in Lipid Rafts at the Non-Permissive Temperature in Btr Cells

Since a considerable fraction of Arid3a resides in the lipid rafts of both B lymphocytes and in Arid3atransfected non-B cells (Schmidt et al., 2009), we sought to determine if localization there was required for senescence rescue. Btr cells were infected with retroviruses encoding $\mathrm{E} 1 \mathrm{~A}$, or wild-type Arid3a or Arid3a substitution mutants C342D, C442S and $401 \mathrm{KIKK} / \mathrm{AIAA}$. These cells were grown at the permissive temperature for two days following shift to the non-permissive temperature for ten days. Lipid rafts 
were prepared by separating crude plasma membrane from lipid rafts via discontinuous gradient centrifugation in ice-cold TNE buffer exactly as previously described (Schmidt et al., 2009). Lipid rafts (buoyant fraction) and plasma membranes (sediment fraction) were collected and analyzed by Western blotting with antibodies against E1A, Ras and the V5 tag affixed to the N-termini all Arid3a constructs.

As shown in Fig. 8, only wild type Arid3a and the mutant $401 \mathrm{KIKK} / \mathrm{AIAA}$ transfectants were capable of growth at the non-permissive temperature; neither the lipid raft localization-defective mutant C342S/D (Wilsker et al., 2005; Schmidt et al., 2009), nor the DNA binding inactive form W299A/Y330A (Nixon et al., 2004) transfectants grow at the non-permissive temperature. We conclude that lipid raft occupancy, DNA binding activity and active cytoplasmic-nuclear shuttling are requisite for Arid3a to function as an oncogene.

\section{Discussion}

Players critical to the senescence response (e.g., p19Arf, p53, p16INK4a and the pRb family) are highly controlled and likely represent components of more extensive signaling networks (Fukuyo et al., 2004; DeCaprio, 2009). Peeper et al. (2002) described the identification of another component, DRIL1/hArid3a, whose orthologue in mice is involved in tissue-specific transcriptional regulation. Here we have compared the properties of the human and mouse genes. In primary murine fibroblasts, both Arid3as bypass not only RASV12-induced senescence, but also spontaneous senescence. Arid3a-dependent immortalization did not require interference with senescence-dependent induction of various key regulators of the senescence program, including p16INK4a, p19Arf, p21Cip1 and p53. This is in contrast to the Bmil and Tbx2 proteins, which bypass senescence by down-regulating p19Arf (Jacobs et al., 2000). We observed a potentially important species-specific difference in the significantly lower ability for mouse Arid3a + RASV12- MEFs to undergo transformation in culture or to form tumors in mice.

Although RASV12-expressing Rb family-deficient cells show many features of normal cells undergoing RASV12-induced senescence, including up regulation of p16INK4a, p19Arf, p53 and p21Cip1, they continue to proliferate (Peeper et al., 2001). Apparently, the antiproliferative signals elicited by these proteins require $\mathrm{pRb}$ family proteins to become effective. It appears that a similar situation exists for Arid3a-dependent bypass of (RASV12-induced) senescence. Arid3a-expressing cells, too, possess intact signaling cascades that are activated upon onset of (RASV12-induced) senescence, including expression of two established, critical regulators of senescence, p19Arf and p16INK4a (Humbey et al., 2008). The p53 tumor suppressor remains active and activates its target gene p21Cip1 (Samuelson and Lowe, 1997). Thus, similar to Rb family-deficient cells, Arid3aexpressing cells show a normal biochemical response to RASV12 expression. However, they fail to show the normal biological response; i.e., instead of undergoing replicative arrest, they continue to proliferate.

We found that, mArid3a + RASV12 immortalization of MEFs is correlated with $\mathrm{pRb}$ hyperphosphorylation and accumulation of CYCLIN E. The results of (Peeper et al., 2002) showed that hArid3a expression leads to induction of the G1/S CYCLIN E and importantly, that CYCLIN E -/- MEFs are incapable of supporting hArid3a immortalization. CYCLIN E transcription is controlled by $\mathrm{pRb}$ family proteins and their effectors, the E2F family of transcription factors (Ohtani et al., 1995). CYCLIN E is de-repressed in Rbdeficient fibroblasts (Herrera et al., 1996) and collaborates with RASV12 to transform primary cells and to induce tumors (Vidal et al., 2002; Pagliarini and Xu, 2003; Deng et al., 2005; Labalette et al., 2008). Although de-repression of CYCLIN E in Rb-/- MEFs is insufficient for their immortalization, (Peeper et al., 2002) further showed that ectopic over-expression of CYCLIN E1 (but not CYCLIN D1) does lead to immortalization of primary fibroblasts. This observation fits well with the reported order of D- and E-type CYCLIN action, where D phosphorylates $\mathrm{Rb}$ before $\mathrm{E}$ (Leng et al., 2002). It also is consistent with the insensitivity of both $\mathrm{h}$ and mArid3a cells to increased levels of p16INK4a, which is known to block Rb-dependent proliferation (Lukas et al., 1995; Medema et al., 1995). Neither our data, nor that of (Peeper et al., 2002), eliminate the potential contribution of other CYCLINs. While CYCLINs D and E were the obvious targets, CYCLIN A and even the mitotic CYCLIN B1 have been identified as E2F family member targets (Attwooll et al., 2004).

As with mouse Arid3a, simultaneous inactivation of $\mathrm{Rb}$ and its family member p107, in the context of the RASV12 oncoprotein, results in loss of proliferative control, but in only modest oncogenicity in mice (Peeper et al., 2001). In contrast, hArid3a/DRIL1RASV12 cells are potently tumorigenic in mice. Perhaps hArid3a deregulates (yet to be identified) factors not affected by mArid3a, which in concert with a deregulated $\mathrm{pRb}$ pathway underlies its enhanced transformation and oncogenic activities. Mouse and hArid3a align poorly from residues 26-240 (just Nterminal to their ARIDs) where 15 gaps are required to achieve an identity/similarity of $75 / 85 \%$ (data not shown). Conserved within this region for mouse, but not for human Arid3a, is an acidic stretch, which meets consensus requirements for 3 tandem PEST motifs. PEST domains have been shown in several cases to target both ubiquitin-mediated proteosome degradation (Rogers et al., 1986). 
Consistent with a role for DRIL1/hArid3a in human oncogenesis is its localization at chromosomal region 19 p13.3, a region commonly altered in Non-Hodgkins B cell Lymphoma (NHL) and in breast epithelial malignancies (Mitelman et al., 1997). We and others (DP and Rene Benards, personal communication) have observed that hArid3a is highly expressed in malignant colon cell lines (no 19p13 disruptions), as well as in breast cell lines and primary isolates carrying disruptions at $19 \mathrm{p} 13$. In both breast and NHL, these $19 \mathrm{p} 13$ disruptions associate with aggressive growth and bad prognosis. Over 100 genes have been mapped to this telomeric region (Mitelman et al., 1997; Archer et al., 2005). While, there are no data in the public sector that link any of these genes to the disruption, it will be informative to determine formally whether the implicated lesion is within hArid3a.

The senescence bypass and E2F activation induced by Arid3a from either species is relatively slow. This is consistent with the view that the two processes are connected, but why so time-consuming? One possibility is that these effects require chromatin remodeling. Consistent with this notion, mArid3a MAR binding within the immunoglobulin heavy chain enhancer leads to bending of DNA up to 90 degrees (Kaplan et al., 2001). This was shown to facilitate spatially distant interactions of MARs. In addition, Arid3a has been shown to bind directly to model substrates wrapped into nucleosomal structures. A number of ARID domaincontaining proteins have been implicated in chromatin remodeling, including the SWI1 member of the SWI/SNF family (Kortschak et al., 1998; Wang et al., 2004).

Schmidt et al. (2009) correlate presence of a transcription factor (Arid3a) in lipid rafts with modulation events of BCR signaling. Ratliff et al. (2014) provide further motivation for mechanistic studies of Arid3a in lieu of its indirect involvement in the pathogenesis of pediatric and adult manifestations of Systemic Lupus Erythematosus (SLE) through regulation of miR125, a member of the down-regulators of Arid3a. This ties in nicely with a report demonstrating that pediatric manifestations of SLE are associated with a higher risk of tumor development as individuals mature (Bernatsky et al., 2013). Lipid rafts are recognized as platforms for signaling (Staubach and Hanisch, 2011). Oncogenic RasV12 in lipid rafts strongly enhances phosphorylation of EGF receptors (Casar et al., 2009). These observations further correlate with our observation that E1A, as well as Arid3a, localized within lipid rafts at the non-permissive temperature.

Our studies have added yet another Arid3a lipid rafts function-cancer. Targeting lipid rafts for cancer prevention and treatment represent a growing in cancer progression, including cancer cell migration and invasion (Mollinedo and Gajate, 2015) and because cancer-related proteins have been identified in unbiased proteomics analyses of lipid rafts (Lesley et al., 1993). The spread of cancer is dependent on cell adhesion as regulation of this metastatic process holds promise for therapeutic intervention. For examine CD44, a principal cell adhesion receptor expressed in numerous malignant cell types (Senbanjo and Chellaiah, 2017), has been recently demonstrated as a lipid rafts occupant (Hryniewicz-Jankowska et al., 2014). We showed previously that Arid3a affiliation with lipid rafts requires its palmitoylation at C342 (Schmidt et al., 2009). Such a general mechanism has been implicated in breast cancer (Babina et al., 2014).

While it may be tempting to speculate about the function of Arid3a in modulation signals in lipid rafts in the presence of Ras in BTR cells at the nonpermissive temperature, further experimentation is required to explicate this Bright path cells might follow (Herrscher et al., 1995).

\section{Materials and Methods}

\section{Expression Vectors}

Full-length (1-601) HA-tagged mouse (m) and human (h) Arid3a were cloned as described (Kortschak et al., 1998; Herrscher et al., 1995) into the eukaryotic CMV-powered expression vector pCR3.1. Inserts were removed and engineered into pBABE-puro retroviruses. Construction of full-length Ha-rasV12 was described (Peeper et al., 2002). The sequences of the inserts were confirmed by sequencing of both strands. Both of the original, subcloned Arid3a cDNAs were identical to the published sequence (Kortschak et al., 1998; Herrscher et al., 1995).

\section{Preparation of MEFs, Cell Culture and Retroviral Infection}

Organs and head were removed from a 15 day old mouse embryo and the remaining tissue was washed in Phosphate Buffered Saline (PBS) and minced. After a second PBS wash, the tissue was incubated with $100 \mu \mathrm{l}$ trypsin/EDTA (Gibco) on ice for $12 \mathrm{hr}$. The tissue was incubated with $100 \mu \mathrm{l}$ trypsin/EDTA at $37^{\circ} \mathrm{C}$ for $30 \mathrm{~min}$, dissociated in complete medium and transferred to a $100-\mathrm{mm}$ dish. MEFs were maintained in DMEM (Gibco) supplemented with 10\% FBS (PAA Laboratories) and 0.1 $\mathrm{mM} \beta$-mercapto ethanol. These MEFs were designated as passage 1 and were maintained in the same media.

Phoenix packaging cells were used to generate ecotropic retroviruses as described (Serrano et al., $1997 b)$. MEFs were infected with filtered $(0.45 \mu \mathrm{m})$ viral supernatant, supplemented with $4-8 \mu \mathrm{g} / \mathrm{ml}$ polybrene. In general, a single infection round of $6 \mathrm{hrs}$ was sufficient to infect at least $90 \%$ of the population. Btr cells 
(Peeper et al., 2002) were maintained at $32^{\circ} \mathrm{C}$ and infected using viruses as described above.

\section{Proliferation Curves and Cell-Cycle Analysis}

To obtain proliferation curves, MEFs were infected with either empty, HA-Arid3a and/or human Ha-ras V12-containing pBABE-puro retroviral vectors (Peeper et al., 2002) and after 1-2 days were selected with puromycin $\left(1-3 \mu \mathrm{g} \mathrm{ml} \mathrm{m}^{-1}\right)$ for 4 days. After confirming that all mock-infected cells were dead, $\sim 2.5 \times$ $10^{4}$ cells/ well were plated into 12 -well plates and cell proliferation was measured calorimetrically as previously described (Mosmann, 1983). For proliferation curves, passage 3 MEFs were infected with retroviral vectors carrying selectable markers. At 1-2 days post infection, they were selected with puromycin $(1-3 \mu \mathrm{g} / \mathrm{ml})$ for $5-7$ days. After confirming that all mock-infected cells were dead, the cells were seeded at a density of $\sim 1.5 \times 10^{5}$ cells per $5 \mathrm{~cm}$ plate in which they were split twice a week. The proliferation curves were initiated when MEFs neared the end of normal life span (passage 5). Two independent data points were collected in duplicate for each sample. For cell cycle analysis, cells were permeabilized, stained with propidium iodide and the cell cycle distribution was measured by FluorescenceActivated Cell Sorting (FACS).

\section{Senescence-Associated $\beta$-Galactosidase Staining}

Senescence-associated $\beta$-galactosidase activity was detected as previously described (Dimri et al., 1995). Cells were washed once with PBS ( $\mathrm{pH} 7.2$ ), fixed with $1 \%$ glutaraldehyde in PBS ( $\mathrm{pH} 7.2$ ) for $30 \mathrm{~min}$ at room temperature and washed once in PBS (pH 7.2) supplemented with $1 \mathrm{mM} \mathrm{MgCl}$. Cells were then stained in X-gal solution ( $1 \mathrm{mg} / \mathrm{ml} \mathrm{X-gal,} 120 \mu \mathrm{M} \mathrm{K}_{3} \mathrm{Fe}[\mathrm{CN}]_{6}$, $120 \mu \mathrm{M} \mathrm{K}{ }_{4} \mathrm{Fe}[\mathrm{CN}]_{6}, 1 \mathrm{mM} \mathrm{MgCl}_{2}$ in $\mathrm{PBS}$ at $\mathrm{pH} 6.0$ ) overnight at $37^{\circ} \mathrm{C}$ without $\mathrm{CO}_{2}$. Counterstaining with Eosin (Sigma) was performed according to the manufacturer's instruction.

\section{Western Blotting, IP and Chip}

For Western blotting, cell extracts were prepared in NETN lysis buffer (100 mM NaCl, 0.5\% NP-40, $50 \mathrm{mM}$ TRIS-HCl pH 8.0, $1 \mathrm{mM}$ EDTA, supplemented with a protease inhibitor cocktail (Boehringer), assayed for protein concentration and $50-80 \mu \mathrm{g}$ of clarified extract was resolved on SDS-PAGE gels, followed by transfer onto nitrocellulose membranes and probing with antisera, as described (Kim and Tucker, 2006). Primary antibodies used for Western blotting were R562 (Abcam) for p19ARF, ab9113 (Abcam) for the v5 tag, ab28305 (Abcam) for E1A, 3965 (Cell Signaling) for ras, Ab7 (Calbiochem) for p53 and from Santa Cruz, M156 for p16INK4a, C-19 for p21CIP1, M-20 for Cyclin E, C-22 for Cdk4, H-295 for Cyclin D1 and C-22 for actin. Dr. Julien Sage, Stanford University, kindly provided the anti-Rb antibody (Sage et al., 2000). Affinity-purified, rabbit polyclonal anti-mArid3a generated against full-length bacterially synthesized and purified Arid3a has been described (Herrscher et al., 1995). Enhanced chemoluminescence (Amersham) was used for detection of proteins. Actin and tubulin served as loading controls for all blots. Chip assays were performed using the Upstate Chip Kit (17-295) according to the manufacturer's instructions (Attema et al., 2007). Primer sequences and PCR conditions are available upon request.

\section{Soft Agar Assays and In Vivo Tumorigenesis}

Six days post-infection (carried out as described for proliferation curves), cells were mixed with $2 \mathrm{ml} 0.4 \%$ low-gelling agarose (Sigma type VII) in complete DMEM. Cells $(\sim 2.5 \times 104)$ were seeded into duplicate 6well plates containing solidified $1 \%$ agar $(\sim 2 \mathrm{ml})$ in complete medium. Two weeks later, foci were counted.

The capacity for MEFs to form tumors in athymic nude mice was determined by subcutaneous injection of $\sim 1 \times 106$ cells into each flank. Mice were inspected at weekly intervals and when tumors reached $10 \mathrm{~mm}$ in diameter.

\section{Dual Luciferase Assays}

NIH 3 T3 cells in 6 well plates were co-transfected with $100 \mathrm{ng}$ of reporter construct, $100 \mathrm{ng}$ of pRL-TK (Promega Corp., Madison, Wisconsin) as a normalization control and with $800 \mathrm{ng}$ of each eukaryotic expression vector by Fugene 6 reagent (BMB, Germany). Dual luciferase assays were performed 48 hour after transfection using the Dual Luciferase Assay Kit (Promega Corp., Madison, Wisconsin) according to manufacturer's protocols.

\section{Conclusion}

Uncontrolled growth is an undisputed hallmark of cancer. With our understanding of the role of oncogenes incomplete, this work used rat fibroblasts that contain a temperature sensitive mutant of SV40 as a study object. With much effort needed to delineate mechanisms involved and applicable tuning loops, our preliminary results nevertheless provide experimental evidence in support of the notion that the transcription factor Arid3a, be it direct or indirect, can be likened as a major player in the exacerbation of cancer risks of adolescents with pediatric manifestations of systemic lupus erythematosus.

\section{Acknowledgements}

We thank Drs. Daniel Peeper and Rene Bernards for sharing unpublished data, for helpful discussions and for various reagents, Gary Nolan for retroviral packaging cells, Julien Sage for anti-Rb antiserum and help with the 
Chip assays, David Johnson for E2F clones, Ms. Shan Maika, June Harriss and the animal facility for MEF production and help with oncogenicity assays. Chhaya Das and Maya Ghosh provided expert technical assistance and we are grateful for the administrative assistance provided by Paul Das.

\section{Funding Information}

Haley O. Tucker, Acknowledges financial support from NIH Grant R01CA31534, Cancer Prevention Research Institute of Texas (CPRIT) Grants RP100612, RP120348; and the Marie Betzner Morrow Centennial Endowment.

\section{Author's Contributions}

Christian Schmidt: Designed work, performed experiments, analyzed data, wrote the manuscript and initiated the project.

Dongkyoon Kim: Performed research and analyzed data.

Shawn Mathur, David Covarrubias and Chhaya Das: Performed research.

Mark A. Brown: Analyzed data, wrote the manuscript.

Joachim Storsberg: Analyzed data.

Haley O. Tucker: Designed work, analyzed data, wrote the manuscript and initiated the project.

\section{Ethics}

This article is original and contains unpublished material. The corresponding author confirms that all of the other authors have read and approved the manuscript and there are no ethical issues involved.

\section{References}

Archer, H., S. Gupta, S. Enoch, P. Thompson and A. Rowbottom et al., 2005. Distinct phenotype associated with a cryptic subtelomeric deletion of 19p13.3-pter. Am. J. Med. Genet. A, 136: 38-44.

Attema, J.L., P. Papathanasiou, E.C. Forsberg, J. Xu and S.T. Smale et al., 2007. Epigenetic characterization of hematopoietic stem cell differentiation using miniChIP and bisulfite sequencing analysis. Proc. Natl. Acad. Sci. USA, 104: 12371-12376.

Attwooll, C., E.L. Denchi and K. Helin, 2004. The E2F family: Specific functions and overlapping interests. EMBO J., 23: 4709-4716.

Babina, I.S., E.A. McSherry, S. Donatello, A.D. Hill and A.M. Hopkins, 2014. A novel mechanism of regulating breast cancer cell migration via palmitoylation-dependent alterations in the lipid raft affiliation of CD44. Breast Cancer Res., 16: 1-14.
Bernatsky, S., A.E. Clarke, J. Labrecque, E. von Scheven and L.E. Schanberg et al., 2013. Cancer risk in childhood-onset systemic lupus. Arthritis Res. Theory, 15: 1-4.

Binda, O., J. Roy and P.E. Branton, 2006. RBP1 family proteins exhibit SUMOylation-dependent transcriptional repression and induce cell growth inhibition reminiscent of senescence. Mol. Cell Biol., 26: 1917-1931.

Casar, B., I. Arozarena, V. Sanz-Moreno, A. Pinto and L. Agudo-Ibanez et al., 2009. Ras subcellular localization defines extracellular signal-regulated kinase 1 and 2 substrate specificity through distinct utilization of scaffold proteins. Mol. Cell Biol., 29: 1338-1353.

Dannenberg, J., A. van Rossum, L. Schuijff and H. te Riele, 2000. Ablation of the retinoblastoma gene family deregulates G1 control causing immortalization and increased cell turnover under growth-restricting conditions. Genes Dev., 14: 3051-3064.

DeCaprio, J.A., 2009. How the Rb tumor suppressor structure and function was revealed by the study of Adenovirus and SV40. Virology, 384: 274-284.

Deng, Q., Y. Li, D. Tedesco, R. Liao and G. Fuhrmann et al., 2005. The ability of E1A to rescue ras-induced premature senescence and confer transformation relies on inactivation of both p300/CBP and $\mathrm{Rb}$ family proteins. Cancer Res., 65: 8298-8307.

Dimri, G., X. Lee, G. Basile, M. Acosta and G. Scott et al., 1995. A biomarker that identifies senescent human cells in culture and in aging skin in vivo. Proc. National Acad. Sci. USA, 92: 9363-9367. DOI: 10.1073/pnas.92.20.9363

Docquier, A., P. Augereau, M. Lapierre, P.O. Harmand and E. Badia et al., 2012. The RIP140 gene is a transcriptional target of E2F1. PLoS One, 7: 1-13. DOI: 10.1371/journal.pone.0035839

Fattaey, A., K. Helin, M. Dembski, N. Dyson and E. Harlow et al., 1993. Characterization of the retinoblastoma binding proteins RBP1 and RBP2. Oncogene, 8: 3149-3156.

Ferbeyre, G., E. de Stanchina, E. Querido, N. Baptiste and C. Prives, 2000. PML is induced by oncogenic ras and promotes premature senescence. Genes Dev., 14: 2015-2027.

Fiers, W., R. Contreras, G. Haegemann, R. Rogiers and Van de Voorde et al., 1978. Complete nucleotide sequence of SV40 DNA. Nature, 273: 113-120.

Fridman, A. and M. Tainsky, 2008. Critical pathways in cellular senescence and immortalization revealed by gene expression profiling. Oncogene, 27: 5975-5987. DOI: 10.1038/onc.2008.213 
Fukuyo, Y., K. Mogi, Y. Tsunematsu and T. Nakajima, 2004a. E2FBP1/hDril1 modulates cell growth through downregulation of promyelocytic leukemia bodies. Cell Death Differ., 11: 747-759. DOI: $10.1038 /$ sj.cdd.4401412

Fukuyo, Y., K. Mogi, Y. Tsunematsu and T. Nakajima, 2004b. E2FBP1/hDrill modulates cell growth through downregulation of promyelocytic leukemia bodies. Cell Death Differ., 11: 747-759.

Fukuyo, Y., N. Horikoshi, A.M. Ishov, S.J. Silverstein and T. Nakajima, 2011. The herpes simplex virus immediate-early ubiquitin ligase ICP0 induces degradation of the ICP0 repressor protein E2FBP1. J. Virol., 85: 3356-3366.

Guo, A., P. Salomoni, J. Luo, A. Shih and S. Zhong et al., 2000. The function of PML in p53-dependent apoptosis. Nat. Cell. Biol., 2: 730-736.

Haas, K., C. Johannes, C. Geisen, T. Schmidt and H. Karsunky et al., 1997. Malignant transformation by cyclin $\mathrm{E}$ and Ha-Ras correlates with lower sensitivity towards induction of cell death but requires functional $\mathrm{Myc}$ and $\mathrm{CDK} 4$. Oncogene, 15: 2615-2623.

Harbour, J., R. Luo, A. Dei Santi, A. Postigo and D. Dean, 1999. Cdk phosphorylation triggers sequential intramolecular interactions that progressively block $\mathrm{Rb}$ functions as cells move through G1. Cell, 98: 859-869.

Herrera, R., V. Sah, B. Williams, T. Makela and R. Weinberg et al., 1996. Altered cell cycle kinetics, gene expression and G1 restriction point regulation in $\mathrm{Rb}$-deficient fibroblasts. Mol. Cell Biol., 16: 2402-2407.

Herrscher, R., M. Kaplan, D. Lelsz, C. Das and R. Scheuermann et al., 1995. The immunoglobulin heavy-chain matrix-associating regions are bound by Bright: A B cell-specific trans-activator that describes a new DNA-binding protein family. Genes Dev., 9: 3067-3082.

Hryniewicz-Jankowska, A., K. Augoff, A. Biernatowska, J. Podkalicka and A.F. Sikorski, 2014. Membrane rafts as a novel target in cancer therapy. Biochim. Biophys. Acta, 1845: 155-165.

Humbey, O., J. Pimkina, J.T. Zilfou, M. Jarnik and C. Dominguez-Brauer et al., 2008. The ARF tumor suppressor can promote the progression of some tumors. Cancer Res., 68: 9608-9613.

Jacobs, J., P. Keblusek, E. Robanus-Maandag, P. Kristel and M. Lingbeek et al., 2000. Senescence bypass screen identifies TBX2, which represses Cdkn2a (p19ARF) and is amplified in a subset of human breast cancers. Nat. Genet., 26: 291-299.

Jat, P. and P. Sharp, 1989. Cell lines established by a temperature-sensitive simian virus 40 large-T-antigen gene are growth restricted at the nonpermissive temperature. Mol. Cell Biol., 9: 1672-1681.
Kamijo, T., F. Zindy, M. Roussel, D. Quelle and J. Downing et al., 1997. Tumor suppression at the mouse INK4a locus mediated by the alternative reading frame product p19ARF. Cell, 91: 649-659.

Kaplan, M., R. Zong, R. Herrscher, R. Scheuermann and P. Tucker, 2001. Transcriptional activation by a matrix associating region-binding protein. Contextual requirements for the function of bright. J. Biol. Chem., 276: 21325-21330.

Karsunky, H., C. Geisen, T. Schmidt, K. Haas and B. Zevnik et al., 1999. Oncogenic potential of cyclin $\mathrm{E}$ in T-cell lymphomagenesis in transgenic mice: Evidence for cooperation between cyclin E and Ras but not Myc. Oncogene, 18: 7816-7824.

Kim, D. and P.W. Tucker, 2006. A regulated nucleocytoplasmic shuttle contributes to Bright's function as a transcriptional activator of immunoglobulin genes. Mol. Cell Biol., 26: 2187-2201.

Kim, D., L. Probst, C. Das and P.W. Tucker, 2007. REKLES is an ARID3-restricted multifunctional domain. J. Biol. Chem., 282: 15768-15777.

Knudson, A., 2000. Chasing the cancer demon. Annul. Rev. Genet., 34: 1-19.

Knudson, A., 2001. Two genetic hits (more or less) to cancer. Nat. Rev. Cancer, 1: 157-162. DOI: $10.1038 / 35101031$

Komori, H., M. Enomoto, M. Nakamura, R. Iwanaga and K. Ohtani, 2005. Distinct E2F-mediated transcriptional program regulates p14ARF gene expression. EMBO J., 24: 3724-3736.

Kortschak, R., H. Reimann, M. Zimmer, H. Eyre and R. Saint et al., 1998. The humandead ringer/brighthomolog, DRIL1: cDNA cloning, gene structure and mapping to D19S886, a marker on 19 p13.3 that is strictly linked to the Peutz-Jeghers syndrome. Genomics, 51: 288-292. DOI: 10.1006/geno.1998.5259

Kortschak, R., P. Tucker and R. Saint, 2000. ARID proteins come in from the desert. Trends Biochem. Sci., 25: 294-299.

Kortum, R.L., H.J. Johnson, D.L. Costanzo, D.J. Volle and G.L. Razidlo et al., 2006. The molecular scaffold kinase suppressor of Ras 1 is a modifier of $\mathrm{RasV}^{12}$-induced and replicative senescence. Mol. Cell. Biol., 26: 2202-2214. DOI: 10.1128/MCB.26.6.2202-2214.2006

Kuilman, T. and D.S. Peeper, 2009. Senescencemessaging secretome: SMS-ing cellular stress. Nat. Rev. Cancer, 9: 81-94. DOI: 10.1038/nrc2560

Kurz, D., S. Decary, Y. Hong and J. Erusalimsky, 2000. Senescence-associated $\beta$-galactosidase reflects an increase in lysosomal mass during replicative ageing of human endothelial cells. J. Cell Sci., 113: 3613-3622. 
Labalette, C., Y. Nouet, F. Levillayer, C. Armengol and C. Renard et al., 2008. The LIM-only protein FHL2 mediates ras-induced transformation through cyclin D1 and p53 pathways. PLoS ONE, 3: e3761- e3761.

Land, H., L. Parada and R. Weinberg, 1983. Tumorigenic conversion of primary embryo fibroblasts requires at least two cooperating oncogenes. Nature, 304: 596-602. DOI: 10.1038/304596a0

Leal, J., J. Fominaya, A. Cascon, M. Guijarro and C. Blanco-Aparicio et al., 2008. Cellular senescence bypass screen identifies new putative tumor suppressor genes. Oncogene, 27: 1961-1970.

Leng, X., M. Noble, P.D. Adams, J. Qin and J. Harper, 2002. Reversal of growth suppression by p107 via direct phosphorylation by cyclin D1/cyclindependent kinase 4. Mol. Cell Biol., 22: 2242-2254.

Lesley, J., R. Hyman and P.W. Kincade, 1993. CD44 and its interaction with extracellular matrix. Adv. Immunol., 54: 271-335.

Lin, D., G.C. Ippolito, R. Zong, J. Bryant and J. Koslovsky et al., 2007. Bright/ARID3A contributes to chromatin accessibility of the immunoglobulin heavy chain enhancer. Mol. Cancer, 6: 23-23.

Lleonart, M.E., A. Artero-Castro and H. Kondoh, 2009. Senescence induction; a possible cancer therapy. Mol. Cancer, 8: 1-10. DOI: 10.1186/1476-4598-8-3

Ludlow, J., J. DeCaprio, C. Huang, W. Lee and E. Paucha et al., 1989. SV40 large T antigen binds preferentially to an underphosphorylated member of the retinoblastoma susceptibility gene product family. Cell, 56: 57-65.

Lukas, J., D. Parry, L. Aagaard, D. Mann and J. Bartkova et al., 1995. Retinoblastoma-proteindependent cell-cycle inhibition by the tumour suppressor p16. Nature, 375; 503-506.

Macera-Bloch, L., J. Houghton, M. Lenahan, K.K. Jha and H.L. Ozer, 2002. Termination of lifespan of SV40-transformed human fibroblasts in crisis is due to apoptosis. J. Cell Physiol., 190: 332-344.

Medema, R., R. Herrera, F. Lam and R. Weinberg, 1995. Growth suppression by p16ink4 requires functional retinoblastoma protein. Proc. Natl. Acad. Sci. USA, 92: 6289-6293.

Melchior, F., 2000. SUMO--nonclassical ubiquitin. Annul. Rev. Cell Dev. Biol., 16: 591-626.

Mitelman, F., F. Mertens and B. Johansson, 1997. A breakpoint map of recurrent chromosomal rearrangements in human neoplasia. Nat. Genet., 15: 417-474.

Mollinedo, F. and C. Gajate, 2015. Lipid rafts as major platforms for signaling regulation in cancer. Adv. Biol. Regul., 57:130-46.

Mosmann, T., 1983. Rapid colorimetric assay for cellular growth and survival: application to proliferation and cytotoxicity assays. J. Immunol. Methods, 65: 55-63.
Nixon, J.C., J.B. Rajaiya, N. Ayers, S. Evetts and C.F. Webb, 2004. The transcription factor, Bright, is not expressed in all human B lymphocyte subpopulations. Cell Immunol., 228: 42-53.

Numata, S., P. Claudio, C. Dean, A. Giordano and C. Croce, 1999. Bdp, a new member of a family of DNAbinding proteins, associates with the retinoblastoma gene product. Cancer Res., 59: 3741-3747.

Ohtani, K., J. DeGregori and J. Nevins, 1995. Regulation of the cyclin E gene by transcription factor E2F1. Proc. Natl. Acad. Sci. USA, 92: 12146-12150.

Pagliarini, R.A. and T. Xu, 2003. A genetic screen in Drosophila for metastatic behavior. Science, 302; 1227-1231.

Palmero, I., C. Pantoja and M. Serrano, 1998. p19 ARF links the tumour suppressor p53 to Ras. Nature, 395: 125-126.

Pearson, M., R. Carbone, C. Sebastiani, M. Cioce and M. Fagioli et al., 2000. PML regulates p53 acetylation and premature senescence induced by oncogenic Ras. Nature, 406: 207-210.

Peeper, D., J. Dannenberg, S. Douma, H. te Riele and R. Bernards, 2001. Escape from premature senescence is not sufficient for oncogenic transformation by Ras. Nat. Cell Biol., 3: 198-203. DOI: $10.1038 / 35055110$

Peeper, D.S., A. Shvarts, T. Brummelkamp, S. Douma and E.Y. Koh et al., 2002. A functional screen identifies hDRIL1 as an oncogene that rescues RASinduced senescence. Nat. Cell Biol., 4: 148-153.

Rajaiya, J., J.C. Nixon, N. Ayers, Z.P. Desgranges and A.L. Roy et al., 2006. Induction of immunoglobulin heavy-chain transcription through the transcription factor Bright requires TFII-I. Mol. Cell Biol., 26: 4758-4768.

Rajaiya, J., M. Hatfield, J.C. Nixon, D.J. Rawlings and C.F. Webb, 2005. Bruton's tyrosine kinase regulates immunoglobulin promoter activation in association with the transcription factor Bright. Mol. Cell Biol., 25: 2073-2084.

Ratliff, M.L., T.D. Templeton, J.M. Ward and C.F. Webb, 2014. The Bright Side of Hematopoiesis: Regulatory Roles of ARID3a/Bright in Human and Mouse Hematopoiesis. Front Immunol., 5: 113-113.

Rhee, C., B.K. Lee, S. Beck, A. Anjum and K.R. Cook et al., 2014. Arid3a is essential to execution of the first cell fate decision via direct embryonic and extraembryonic transcriptional regulation. Genes Dev., 28: 2219-2232.

Rhee, C., M. Edwards, C. Dang, J. Harris and M. Brown et al., 2017. ARID3A is required for mammalian placenta development. Dev. Biol., 422: 83-91.

Rogers, S., R. Wells and M. Rechsteiner, 1986. Amino acid sequences common to rapidly degraded proteins: The PEST hypothesis. Science, 234: 364-368. 
Ruley, H., 1983. Adenovirus early region 1A enables viral and cellular transforming genes to transform primary cells in culture. Nature, 304: 602-606.

Sage, J., G. Mulligan, L. Attardi, A. Miller and S. Chen et al., 2000. Targeted disruption of the three $\mathrm{Rb}$ related genes leads to loss of G1 control and immortalization. Genes Dev., 14: 3037-3050. DOI: $10.1101 / \operatorname{gad} .843200$

Samuelson, A. and S. Lowe, 1997. Selective induction of p53 and chemosensitivity in RB-deficient cells by E1A mutants unable to bind the RB-related proteins. Proc. Natl. Acad. Sci. USA, 94: 12094-12099.

Schmidt, C., D. Kim, G.C. Ippolito, H.R. Naqvi and L. Probst et al., 2009. Signalling of the BCR is regulated by a lipid rafts-localised transcription factor, Bright. EMBO J., 28: 711-724.

Sebastian, T., R. Malik, S. Thomas, J. Sage and P.F. Johnson, 2005. C/EBP $\beta$ cooperates with RB: E2F to implement $\mathrm{Ras}^{\mathrm{V} 12}$-induced cellular senescence. EMBO J., 24: 3301-3312.

Seger, Y.R., M. Garcia-Cao, S. Piccinin, C.L. Cunsolo and C. Doglioni et al., 2002. Transformation of normal human cells in the absence of telomerase activation. Cancer Cell, 2: 401-413.

Senbanjo, L.T. and M.A. Chellaiah, 2017. CD44: A multifunctional cell surface adhesion receptor is a regulator of progression and metastasis of cancer cells. Front Cell Dev. Biol., 5: 1-18.

Serrano, M., A. Lin, M. McCurrach, D. Beach and S. Lowe, 1997a. Oncogenic ras provokes premature cell senescence associated with accumulation of p53 and $\mathrm{p}^{16 \mathrm{INK} 4 \mathrm{a}}$. Cell, 88: 593-602. DOI: 10.1016/S0092-8674(00)81902-9

Serrano, M., A. Lin, M. McCurrach, D. Beach and S. Lowe, 1997b. Oncogenic ras provokes premature cell senescence associated with accumulation of p53 and p16INK4a. Cell, 88: 593-602.

Staubach, S. and F.G. Hanisch, 2011. Lipid rafts: Signaling and sorting platforms of cells and their roles in cancer. Exp. Rev. Proteom., 8: 263-77.

Suzuki, M., S. Okuyama, S. Okamoto, K. Shirasuna and T. Nakajima et al., 1998. A novel E2F binding protein with Myc-type HLH motif stimulates E2F-dependent transcription by forming a heterodimer. Oncogene, 17: 853-865. DOI: 10.1038/sj.onc. 1202163

Tegtmeyer, P., 1975. Function of simian virus 40 gene A in transforming infection. J. Virol., 15: 613-618.
Vidal, A., S. Millard, J.P. Miller and A. Koff, 2002. Rho activity can alter the translation of p27 mRNA and is important for RasV12-induced transformation in a manner dependent on p27 status. J. Biol. Chem., 277: 16433-16440.

Wang, X., N.G. Nagl, D. Wilsker, M. Van Scoy and S. Pacchione et al., 2004. Two related ARID family proteins are alternative subunits of human SWI/SNF complexes. Biochem. J, 383: 319-325.

Webb, C., R. Zong, D. Lin, Z. Wang and M. Kaplan et al., 1999. Differential regulation of immunoglobulin gene transcription via nuclear matrix-associated regions. Cold Spring Harb Symp. Quant. Biol., 64: 109-118.

Webb, C., Y. Yamashita, N. Ayers, S. Evetts and Y. Paulin et al., 2000. The transcription factor Bright associates with Bruton's tyrosine kinase, the defective protein in immunodeficiency disease. J. Immunol., 165: 6956-6965.

Webb, C.F., E.A. Smith, K.L. Medina, K.L. Buchanan and G. Smithson et al., 1998. Expression of bright at two distinct stages of B lymphocyte development. J. Immunol., 160: 4747-4754.

Weinberg, R., 1989. Oncogenes, antioncogenes and the molecular bases of multistep carcinogenesis. Cancer Res., 49: 3713-3721.

Weinberg, R., 1997. The cat and mouse games that genes, viruses and cells play. Cell, 88: 573-575.

Wilsker, D., L. Probst, H.M. Wain, L. Maltais and P.W. Tucker et al., 2005. Nomenclature of the ARID family of DNA-binding proteins. Genomics, 86: 242-251. DOI: 10.1016/j.ygeno.2005.03.013

Wong, J.V., G. Yao, J.R. Nevins and L. You, 2011. Viralmediated noisy gene expression reveals biphasic E2f1 response to MYC. Mol. Cell, 41: 275-85.

Yang, Q., 2008. Cellular senescence, telomere recombination and maintenance. Cytogenet. Genome Res., 122: 211-218.

Zhang, H., M. Gavin, A. Dahiya, A. Postigo and D. Ma et al., 2000. Exit from G1 and S phase of the cell cycle is regulated by repressor complexes containing HDAC-Rb-hSWI/SNF and RbhSWI/SNF. Cell, 101: 79-89.

Zong, R.T., C. Das and P.W. Tucker, 2000. Regulation of matrix attachment region-dependent, lymphocyterestricted transcription through differential localization within promyelocytic leukemia nuclear bodies. EMBO J., 19: 4123-4133.

Zou, Y., S. Misri, J.W. Shay, T.K. Pandita and W.E. Wright, 2009. Altered states of telomere deprotection and the two-stage mechanism of replicative aging. Mol. Cell Biol., 29: 2390-2397. 